ALICE CHOTE

\title{
THE RESOLUTION OF INTERNATIONAL WATERCOURSE DISPUTES: HOW SHOULD STATES APPROACH THE MATTER?
}

\author{
LLM RESEARCH PAPER
}

LAWS 521: INTERNATIONAL ARBITRATION

FACULTY OF LAW

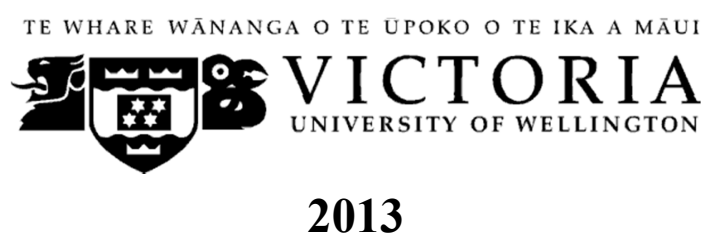




\section{Contents}

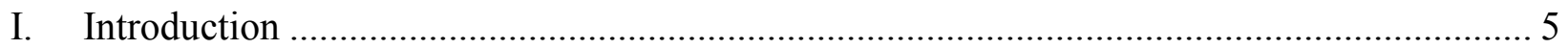

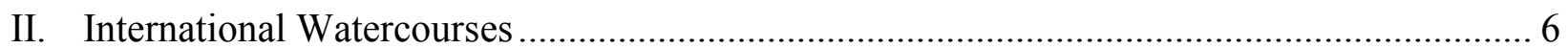

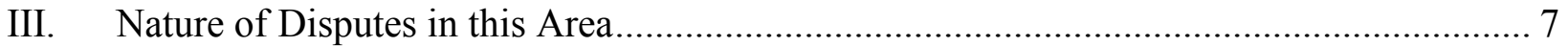

A. Legal Framework: The United Nations Convention on the Non-Navigational Uses of

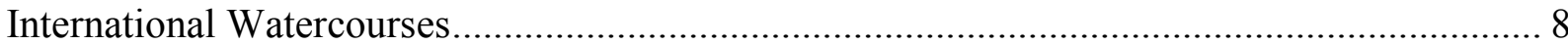

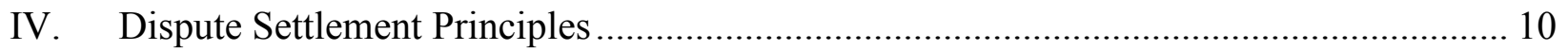

A. United Nations Convention on the Law of the Non-Navigational Uses of International

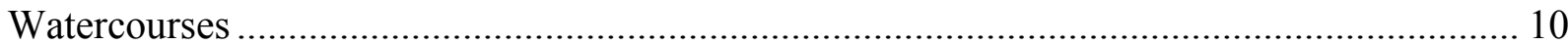

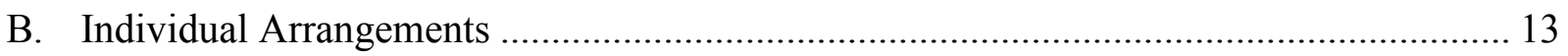

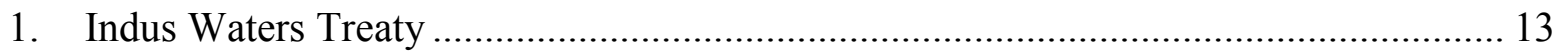

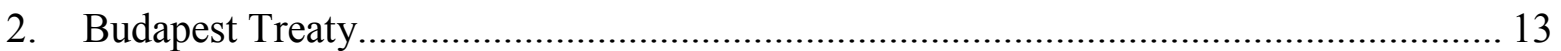

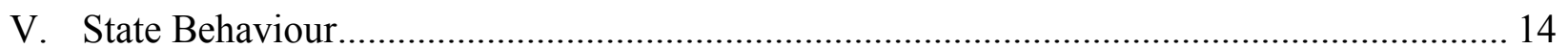

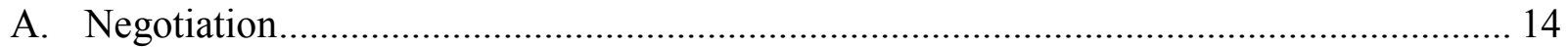

1. Benefits of the Negotiation Process ........................................................................ 15

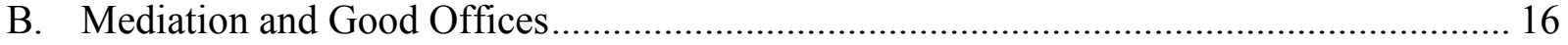

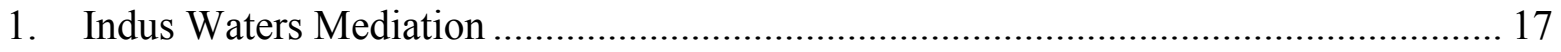

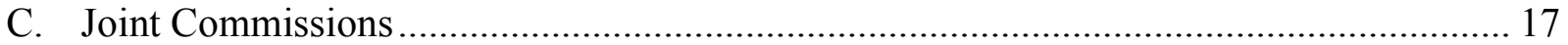

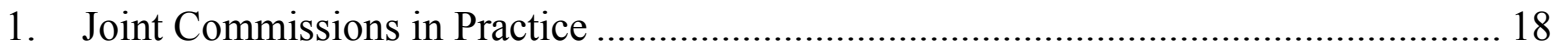

(a) International Joint Commission ..................................................................... 19

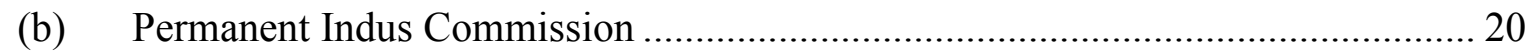

D. International Court of Justice ................................................................................... 21

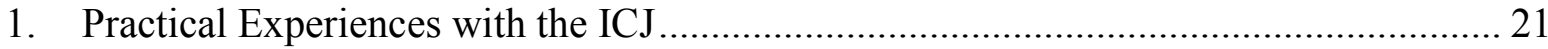

(a) Diversion of Water from the River Meuse ....................................................... 22

(b) Case Concerning the Gabčikovo-Nagymaros Project ........................................ 23

(c) Pulp Mills on the River Uruguay .................................................................... 26

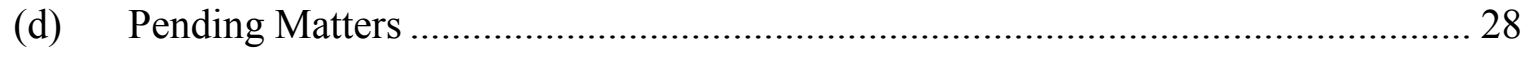

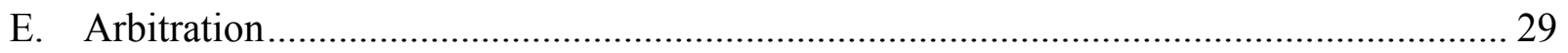

1. Practical Experience with Arbitration ................................................................. 29 


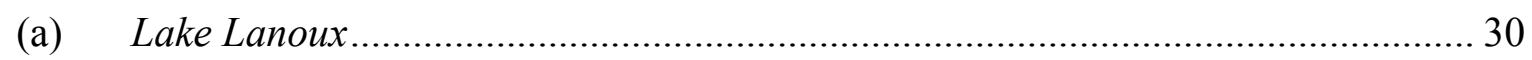

(b) Indus Waters Kishengana Arbitration ...................................................................... 31

VI. Not the UN Convention Approach .......................................................................... 34

A. Why has fact finding not been used in this context? ........................................................ 34

VII. A Possible Approach for States ……………….............................................................. 37

A. Joint Commissions and Fact Finding ............................................................................. 38

1. Why should fact finding be used as a first step? ........................................................ 40

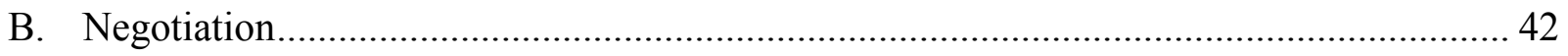

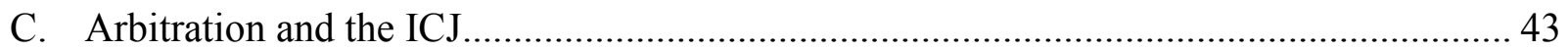

1. Potential Distinction between Adjudication and Arbitration ........................................ 44

D. The International Law Commissions Approach ............................................................... 46

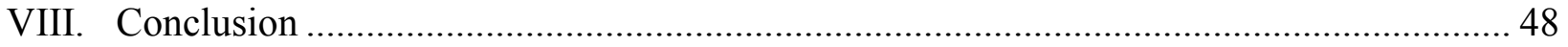

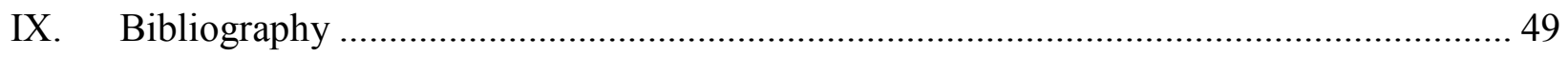

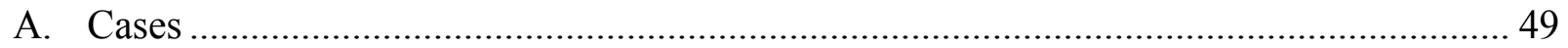

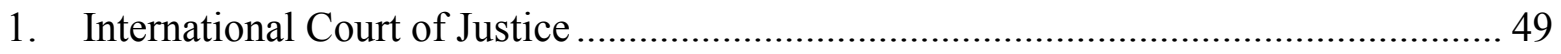

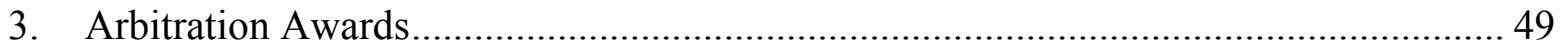

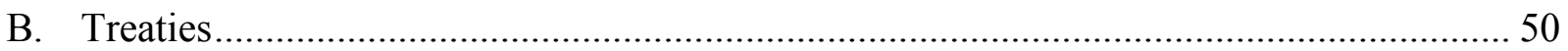

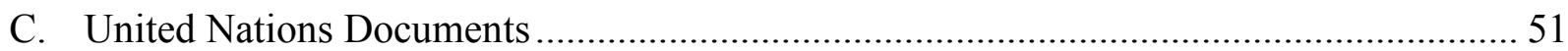

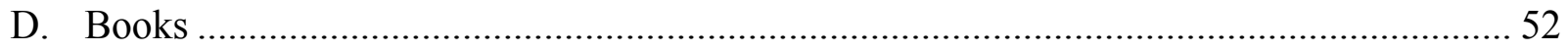

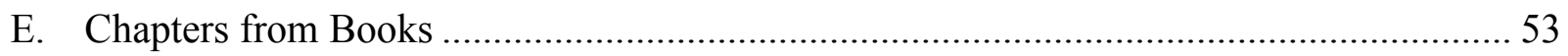

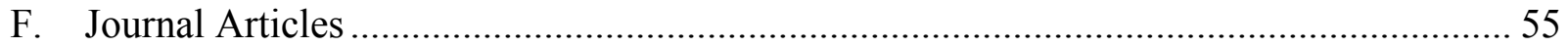

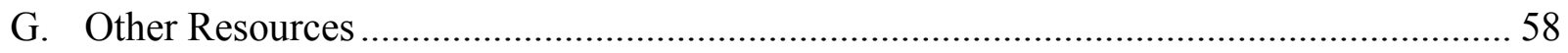

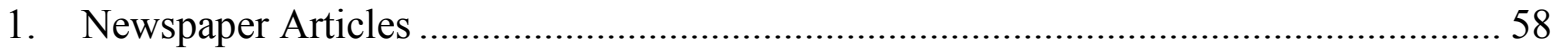

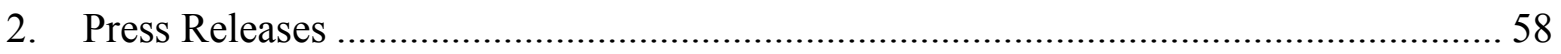

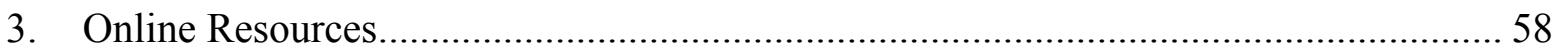


Disputes concerning international watercourses have been resolved in a variety of ways in the past. This paper builds upon the dispute resolution framework put forward in the United Nations Convention on the Law of the NonNavigational Uses of International Watercourses and state practice to develop a dispute resolution framework which will bring more efficient results for riparian states. This process emphasises the important role that fact finding can have in this context. Using this investigative process at an early stage in the dispute resolution process helps to reduce the areas of conflict between the states and provides a platform to encourage negotiations. The framework outlined also allows for recourse to negotiations, and the International Court of Justice (ICJ) or arbitration if a resolution cannot be found. Recourse to the ICJ and arbitral tribunals has been left to the final stage of the framework to reflect state practice in the area. If this style of dispute resolution framework is adopted by states it should allow for disputes to be resolved efficiently. In turn this is likely to increase the awareness and support for fact finding as an alternative means of dispute resolution in international relations more broadly.

Key Words: dispute resolution, international watercourse, fact finding.

The text of this paper (excluding abstract, table of contents, footnotes and bibliography) comprises approximately 14,987 . 


\section{Introduction}

Water is a precious resource, vital for sustaining life. It is also a resource which is becoming increasingly scarce as the world's population continues to grow. One of the main issues connected with the world's increasing demands for water is that a large proportion of the water used by states is drawn from shared resources. ${ }^{1}$ As demand increases, the amount of water drawn from these shared resources also increases. This can detrimentally impact other riparian states as the quantity and quality of water they receive may deteriorate.

The adverse impacts of increasing the amount of water drawn from a shared resource can result in disputes between states as to the nature of each states right to use the resource, and the conditions of such use. There is the scope for these disputes to intensify due to the essential nature of clean water access. This risk of conflict was emphasised by the World Bank's Vice President for Environmentally Sustainable Development, Ismael Serageldin, in 1995 when he said that "many of the wars of this century were about oil, but wars of the next century will be over water". ${ }^{2}$ It is the aim of this paper to explore the mechanisms that states can use to resolve the issues that they have relating to the use of water without resorting to physical conflict.

The United Nations Convention on the Law of the Non-Navigational Uses of International Watercourses 1997 (UN Convention) provides states with a framework for dispute resolution. However, to date states have not followed this process to its conclusion. State practice demonstrates that states have preferred to use binding third party dispute resolution as a final step when resolving their disputes, rather than resorting to fact finding which is the final stage of the UN Convention. This result is somewhat surprising considering that decisions from the International Court of Justice (ICJ) and arbitral tribunals in this area have not always provided parties with practical decisions which have allowed them to move forward in their relationships.

The practice adopted by states may reflect a perception that fact finding adds little to the process of dispute resolution once the matter has gone through a legal or arbitral process. States' reluctance to engage in fact finding also reflects the relative neglect that this process has had in recent times, despite its lengthy history. Although the United Nations (UN) has increasingly

\footnotetext{
${ }^{1}$ There are over 300 watercourses shared by two or more states globally. Patricia Wouters "Universal and Regional Approaches to Resolving International Water Disputes: What Lessons Learned From State Practice?" in The International Bureau of the Permanent Court of Arbitration (ed) Resolution of International Water Disputes (Kluwer Law International, The Hague, 2003) 111 at 114.

${ }^{2}$ Barbara Crossette "Severe Water Crisis Ahead for Poorest Nations in Next 2 Decades" The New York Times (New York, 10 August 1995).
} 
made use of fact finding since the Agenda for Peace was launched in 1992, it still remains largely ignored. In light of this, this paper will argue that fact finding can be of practical use in the dispute resolution process but only if it is engaged with in the early stages of the dispute resolution process.

To demonstrate how fact finding could operate in practice the final part of this paper puts forward a suggested structure for dispute resolution in the context of international watercourses. The process mooted combines elements of the UN Convention and state practice. It provides for states to begin to resolve a dispute using fact finding procedures. If this process is insufficient to resolve the matter the information found through the fact finding process can be used as a basis for direct negotiations. It is envisaged this will enable states to resolve the majority of disputes in this area. If these steps prove unsuccessful, the final option is for states to submit the matter to either the ICJ or an arbitral tribunal for determination. This final stage reflects the general reluctance by states to submit disputes to a third party for determination and mirrors state practice in this area. ${ }^{3}$

The first part of this paper will provide a broad overview of the law and dispute resolution processes available in the context of international watercourses. It will go on to show how these processes have been used in practice by states. The second part focuses on why the way states approach the issue has differed from that set out in the UN Convention. Finally, the paper sets out an alternative approach that can be adopted by states. It is argued that this approach is likely to be more successful than both the UN Convention approach, and those processes undertaken by states without a joint commission established to deal with watercourse matters. A move towards this suggested structure in this area has the power to resolve more watercourse disputes at an earlier stage in the process which will lessen the likelihood that states will engage in physical conflict over rights in international watercourses in the coming years.

\section{International Watercourses}

There are a wide range of bodies of water on the earth, from rivers and lakes to the sea, each of which can be subject to quite different types of disputes. As this paper is focusing on dispute resolution, it is important that the subject matter of the disputes examined is relatively similar. In order to achieve this, the scope of the paper will be confined to disputes concerning international watercourses.

\footnotetext{
${ }^{3}$ J. G. Merrils International Dispute Settlement $\left(4^{\text {th }}\right.$ ed, Cambridge University Press, Cambridge, UK, 2005) at 63; Geoffrey Palmer "Perspectives on International Dispute Settlement from a Participant" (2012) 43 VUWLR 36 at 72 ; John Merrils "The Means of Dispute Settlement" in Malcolm D. Evans (ed) International Law (2 ${ }^{\text {nd }}$ ed, Oxford University Press, New York, 2006) 533 at 547-548.
} 
Watercourses are defined in the UN Convention as "a system of surface waters and groundwaters constituting by virtue of their physical relationship a unitary whole and normally flowing into a common terminus". 4 These bodies of water are internationalized when they flow between two or more states, or when they form the border between two states. Although watercourses are broadly defined in the UN Convention, this paper will focus on the above ground aspect of the watercourse system, due to the different rules that to underground aquifers.

The scope of this paper will be further confined by focusing on issues related to the development and management of an international watercourse, rather than navigational or boundary related issues. The issues focussed on arise due to the variety of uses for a watercourse. Not only can the water be drawn to supply drinking water to a population, it also has a range of economic uses. Water is an essential resource in growing crops, and many industrial processes. With changes in technology rivers can also provide a means of producing electricity through the establishment of hydro-electric power stations. ${ }^{5}$

All of these activities can have an impact on other users of the water resource through reducing the water supply, polluting the waterway or causing flooding through damming. It is important that states recognize the adverse effects that their actions can have on other states, even if the activity they are undertaking has positive implications for their own population. A range of specific disputes will be discussed in later sections of this paper which will provide clear examples of the nature of the problems that can arise through the development of a watercourse.

\section{Nature of Disputes in this Area}

The adverse impact that the development of a watercourse by one state can have on another is generally the starting point for a dispute. In order to minimise these disputes, principles of international law have arisen to provide states with guidelines for the acceptable development of an international watercourse.

\footnotetext{
${ }^{4}$ Convention on the Law of the Non-Navigational Uses of International Watercourses (opened for signature 25 May 1997, not yet in force), art 2 [Watercourse Convention].

${ }^{5}$ Attila Tanzi and Maurizio Arcari The United Nations Convention on the Law of International Watercourses: a framework for sharing (Kluwer Law International, London, 2001) at 7; Stephen C McCaffery The Law of International Watercourses (Oxford University Press, Oxford, UK, 2007) at $49-50$.
} 


\section{A. Legal Framework: The United Nations Convention on the Law of the Non-Navigational Uses of International Watercourses}

The principles of international law that have developed in the context of international watercourses are outlined in the UN Convention. Some aspects of the UN Convention are "widely regarded as reflecting ... rules of customary international law" in the area, despite the UN Convention not yet being in force. ${ }^{6}$ The key principles relating to the use of international watercourses fall within that category. ${ }^{7}$ The first principle which guides the development of an international watercourse is that watercourses must be utilized in a manner that is equitable and reasonable. ${ }^{8}$ The second principle is that the use or development of an international watercourse by one state must not cause significant harm to another riparian state. ${ }^{9}$

Despite these rules being in place problems have arisen in this area due to the apparent inconsistencies between them. ${ }^{10}$ If a state is taking actions to gain an equitable share of a watercourse they may be at risk of causing significant harm to another riparian state in the process, particularly those riparian states that are located further downstream. In order to help resolve this issue the International Law Commission (ILC), through its development of the UN Convention, has attempted to reconcile the need for development of international watercourses, with the protection of states' established uses. ${ }^{11}$

${ }^{6}$ Lucius Caflisch Promoting Justice, Human Rights and Conflict Resolution through International Law (Martinus Nijhoff Publishers, Leiden, the Netherlands, 2007) at 789.

${ }^{7}$ M.M. Rahaman "Principles of International Water Law" (2009) 1(3) International Journal of Sustainable Society 207 at 210; Stephen McCaffery "The UN Convention on the Law of the Non-Navigational Uses of International Watercourses: Prospects and Pitfalls" in M.A. Salman and Laurence Boisson de Chazournes (eds) International Watercourses: Enhancing Cooperation and Managing Conflict (World Bank Technical Paper No. 414, 1998) 17at 24, 27.

${ }^{8}$ See: Watercourse Convention, above n 4, art 6; McCaffery, above n 5, 384-405.

${ }^{9}$ See: Watercourse Convention, above n 4, art 7; McCaffery, above n 5, 406 - 445 .

${ }^{10}$ See: M.A. Salman and Laurence Boisson de Chazournes (eds) International Watercourses: Enhancing Cooperation and Managing Conflict (World Bank Technical Paper No. 414, 1998).

${ }^{11}$ In drafting the UN Convention, the ILC was given the task of codifying the principles of international law in this area, which included the notion that watercourses must be shared equitably and states must refrain from doing harm to others. They had to frame the principles in the Convention in a way that would be acceptable to states and which would allow for the "utilization, development, conservation, management and protection of international watercourses". Progressive development and codification of the rules of international law relating to international watercourses GA Res 2669 A/Res/2669 (1970); Watercourse Convention, above n 4, preamble. As has been noted by Stephen McCaffery, "the language finally adopted by represents an attempt to strike a balance between the equitable-utilization and "no harm" rules." McCaffery, above n 5, at 365. 
In reconciling the principles the UN Convention has applied a principle of limited territorial sovereignty. ${ }^{12}$ This means that states do not have an unlimited right to utilize the water which flows within their territory. It also means that the principle of reasonable and equitable use does not equate to a strictly equal share of the water resource. ${ }^{13}$ Reasonable and equitable use of the water resource is instead determined by looking at a range of relevant factors. Factors considered under the approach in the UN Convention include the geographic and climatic conditions of the riparian states, the economic needs of the states, and the protection of the resource and the availability of alternative resources. ${ }^{14}$

Evaluating a broad range of factors before development proceeds seems to provide some protection for existing uses. However, the provisions relating to the obligation not to cause significant harm appear to weaken this protection. ${ }^{15}$ Article $7(2)$ of the UN Convention provides that if a state undertakes an activity which would cause significant harm to another state, that state shall attempt to mitigate the harm, or "discuss the question of compensation". ${ }^{16}$ This provides a way for states to make use of a watercourse and permissibly cause harm to another riparian state through providing the effected state with compensation. ${ }^{17}$

Even in light of this attempt to reconcile the legal principles, there still remains disagreements as to what constitutes significant harm and in what circumstances monetary compensation is appropriate. Determining where the balance between these two principles should lie is outside of the scope of this paper. For current purposes it is sufficient to recognise that the current uncertainty in this area of international law means that disputes between states will continue to arise. An implication of this is that states will often have to have recourse to various methods of dispute resolution in order to resolve disagreements that occur.

\footnotetext{
${ }^{12}$ This can be contrasted with a principle of absolute territorial sovereignty, or the Harmon doctrine, which saw states argue that they should have the ability to control all watercourses within their territory, without regard for the implications such actions may have on other states. Tanzi and Arcari, above n 5, at $11-15$; McCaffery, above n 5, at $112-147$.

${ }^{13}$ Tanzi and Arcari, above n 5, at $14-15$; McCaffery, above n 5, at $135-147$.

${ }^{14}$ Watercourse Convention, above $\mathrm{n} 4$, art 6(1).

${ }^{15}$ This is because the requirement not to cause harm is not absolute; states may negotiate if there is a risk that harm will be caused and they may provide compensation if this is the case. The rights of the other riparian states should also be taken into account in determining what is equitable use, but they are not determinative. Lusius Caflisch "Regulation of the Uses of International Watercourses" in in M.A. Salman and Laurence Boisson de Chazournes (eds) International Watercourses: Enhancing Cooperation and Managing Conflict (World Bank Technical Paper No. 414, 1998) 3 at 13, 14; McCaffery, above n 5, at 411 - 412; Tanzi and Arcari, above n 5, at $152-154$.

${ }^{16}$ Watercourse Convention, above $\mathrm{n} 4$, art 7(2).

${ }^{17}$ Art 7(2).
} 


\section{Dispute Settlement Principles}

Due to the lack of consensus on the principles that should guide the development and management of an international watercourse, the international community has had to determine appropriate methods to resolve the disputes that arise in this context. In doing this the principle of peaceful settlement of disputes found in the UN Charter remains paramount. ${ }^{18}$

Many states that have a watercourse, such as a river or basin, situated either in their territory, or acting as their boundary, have an agreement with co-riparian states providing for the management of the watercourse. These often contain dispute resolution provisions. However, this is not the case for all states in this situation, especially those that have not utilized the international watercourses in their territory in the past. For the latter group the UN Convention provides practical guidance on dispute settlement in this area.

\section{A. United Nations Convention on the Law of the Non-Navigational Uses of International Watercourses}

The UN Convention was the result of over 30 years of work by the ILC and was opened for signature on 21 May $1997 .{ }^{19}$ To date the UN Convention has been adopted by 30 states, five short of the 35 required for the UN Convention to enter into force. ${ }^{20}$ Despite the UN Convention having not yet entered in force, its provisions are seen as reflecting customary international law. $^{21}$

Article 33 of the UN Convention provides the framework for the peaceful resolution of disputes. This provision was one of the most contentious articles during the development of the UN Convention, and states expressed a range of reservations about it. ${ }^{22}$

Some states objected to the inclusion of any compulsory third party dispute settlement mechanisms. ${ }^{23}$ These states were generally upstream riparians who wanted to protect their strong

\footnotetext{
${ }^{18}$ Charter of the United Nations, art 33.

${ }^{19}$ The Convention was passed by the United Nations General Assembly on 21 May 1997, 103 votes in favour, 3 against (China, Turkey, Burundi) and 27 abstentions. Convention on the Law of the Non-Navigational Uses of International Watercourses A/RES/51/299 (1997).

${ }^{20}$ Watercourse Convention, above $\mathrm{n} \mathrm{4}$, art 36; "Convention on the Law of the Non-Navigational Uses of International Watercourses" United Nations Treaty Database (1 October 2013) $<$ http://treaties.un.org/pages/ViewDetails.aspx?src=TREATY\&mtdsg_no=XXVII-12\&chapter=27\&lang=en $>$.

${ }^{21}$ Rahaman, above $\mathrm{n}$ 7, at 210-211; McCaffery, above $\mathrm{n}$ 7, at 24,27.

${ }^{22}$ Wouters, above $\mathrm{n} 1$, at 121.

${ }^{23}$ Tanzi and Arcari, above n 5, at 281.
} 
position and included states such as France, Israel, Rwanda and India. ${ }^{24}$ In support of this position Israel argued that "parties to a dispute must be allowed to choose the mechanism that is most appropriate for their specific needs and circumstances". 25

A variation on this argument was put forward by states including China and Turkey who argued that binding procedures could be included as options in the UN Convention, but they should still require states consent before they are able to be used. ${ }^{26}$ Huseyin E. Celem on behalf of Turkey commented that: ${ }^{27}$

... it was not appropriate for a framework convention to foresee any compulsory rules regarding the settlement of disputes, [it is] a matter which should be left to the discretion of states concerned.

In support of this position Chinese representatives argued in the General Assembly that the mandatory settlement of disputes would go against the principle of free choice set out in the UN Charter. $^{28}$

However, some states thought that compulsory procedures, which concluded in a binding result, were required in order for a resolution of the dispute to be guaranteed. ${ }^{29}$ In the UN General Assembly Ahmad Kamal, on behalf of Pakistan, stated his country's reservations about the dispute resolution procedure for this reason. ${ }^{30}$ This view seemed to have been shared by the first Special Rapporteur on the topic, Stephen M. Schwebel, who expressed the view that "nonnegotiable impasses as well as dilatory tactics are ... contrary to the long-run interests of all". 31

The final version of Article 33 can be seen as providing a compromise between these rival positions, by providing a final option for dispute resolution that is mandatory to enter at the

\footnotetext{
${ }^{24}$ McCaffery, above n 7, at 26; Convention on the Law of the Non-Navigational Uses of International Watercourses A/RES/51/299 (1997).

${ }^{25}$ Press Release: General Assembly Adopts Convention on Law of Non-Navigational Uses of International Watercourses GA/9248 (1997) at 7-8.

${ }^{26}$ Tanzi and Arcari, above n 5, at 281; See Also: Aaron Schwabach "United Nations Convention on the Law of Non-navigational uses of International Watercourses, Customary International Law, and the Interests of Developing Upper Riparian's" (1998) 33(2) Texas International Law Journal 257 at 274; Press Release, above n 25, at 6.

${ }^{27}$ Press Release, above $\mathrm{n} 25$, at 4.

${ }^{28}$ At 5 .

${ }^{29}$ Tanzi and Arcari, above n 5, at 282.

${ }^{30}$ Press Release, above n 25, 4 -5.

${ }^{31}$ Stephen M Schwebel Third Report on the law of non-navigational uses of international watercourses A/CN.4/348 and Corr.1 (1982) at [488].
} 
instigation of one state involved in the dispute, but does not provide a binding outcome. ${ }^{32}$ Despite this the provision did not receive unanimous support in the working group, further demonstrating the division that it caused. ${ }^{33}$

The final version of Article 33 provides a three stage process for dispute resolution. It begins by stating that in the event of a dispute parties should begin by trying to settle the matter peacefully by engaging in negotiations. ${ }^{34}$ If the parties cannot reach a settlement through negotiations they can jointly seek the use of good officers of, or request mediation or conciliation by, a third party. ${ }^{35}$ States can also make use of a previously established joint watercourse institution, or have recourse to arbitration or the ICJ in order to resolve the matter. ${ }^{36}$

The UN Convention goes on to say that if parties are unable to settle the matter through recourse to the above means within six months, "the dispute shall be submitted, at the request of any of the parties to the dispute, to impartial fact finding" by a commission. ${ }^{37}$ The commission should investigate the allegations made by each state, and make "such recommendations as it deems appropriate for an equitable solution of the dispute, which the parties concerned shall consider in good faith". 38

This final stage shows the compromise. Although states are required to engage in the fact finding process if they do not reach a settlement within six months, they do not have to follow the recommendations that the fact finding commission provides them with. The value of this compromise will be discussed in the final section on the paper, where a different framework for dispute resolution is proposed.

\footnotetext{
${ }^{32}$ P Wouters "The Legal Response to International Water Scarcity and Water Conflicts: The UN Watercourses Convention and Beyond" (1999) 42 German Yearbook of International Law 292 at 315.

${ }^{33}$ Votes: 33 in favor, five against and 25 abstentions. The reasons for states voting against the provision differed, some thought the provisions were too strong and others thought they did not provide adequate protection. Text of the preamble $\left(1^{\text {st }}, 5^{\text {th }}\right.$ and $8^{\text {th }}$ paragraphs), articles 2(c), 8(1), 12 (title), 17(3), 18, 20 and 30 and annex (Arbitration) adopted ad referendum by the Working Group of the Whole: $6^{\text {th }}$ Committee, Working Group of the Whole for the Elaboration of a Convention on the Law o the Non-Navigational Uses of International Watercourses A/C.6/51/NUW/WG/L.3/Add.1 (1997); Wouters, above n 32, at 315-6.

${ }^{34}$ Watercourse Convention, above n 4, art 33(1).

${ }^{35} \operatorname{Art} 33(2)$.

${ }^{36}$ Art 33(2). There is an annex to the convention setting out the structure of arbitration. Interestingly this provides a time limit for any arbitral decision to be rendered within. Article 14 of the Annex provides that decisions must be issued within five months of the tribunal being fully constituted, although they may take an extra five months if an extension is necessary.

${ }^{37} \operatorname{Art} 33(3)$.

${ }^{38} \operatorname{Art} 33(8)$.
} 


\section{B. Individual Arrangements}

As was noted above, many states that share a watercourse have agreements in place relating to its management. These agreements often include dispute resolution provisions which are similar to the UN Convention although the options may be placed in a different order from the UN Convention to reflect the parties' preferences.

One of the key differences in the structure of the dispute resolution provisions in specific watercourse agreements is that they often include the establishment of a joint commission. Joint commissions regularly have a role in the day-to-day management of the watercourse putting them in a good position to resolve any disagreements between the states. This is different from the UN Convention conception, which sees them as an institution to be engaged with once negotiations between the parties fail.

\section{Indus Waters Treaty}

An example of an individualised agreement is the 1960 Indus Waters Treaty between India and Pakistan. Article 18 provides that if any questions relating to the interpretation, application or breach of the Treaty arise the matter shall first be examined by the Permanent Indus Commission (PIC). The PIC "will endeavour to resolve the question by agreement". 39 If the matter cannot be resolved by the PIC, it may be resolved by the governments through negotiation. ${ }^{40}$ This may be aided by the services of a mediator. ${ }^{41}$ If the parties cannot resolve the dispute through negotiated means the matter can be submitted to arbitration. ${ }^{42}$ Under the agreement a Court of Arbitration can be unilaterally established in order for the dispute to be resolved. ${ }^{43}$

\section{Budapest Treaty}

However, even if an agreement between the states is in place the parties may not have turned their minds to detailed dispute resolution mechanisms like those in the UN Convention or the Indus Waters Treaty. This was the case with the Budapest Treaty of 16 September 1977 on the Construction and Operation of the Gabčíkovo-Nagymaros System of Locks on the Danube (Budapest Treaty). Article 27 simply stated that " $[\mathrm{t}]$ he settlement of disputes in matters relating to the realisation and operation of the System of Locks shall be a function of the government

\footnotetext{
${ }^{39}$ Indus Waters Treaty, India-Pakistan 419 UNTS 126 (Signed 19 September 1960), art 18(1).

${ }^{40}$ Art 18(4).

${ }^{41}$ Art 18(4).

42 Art 18(5).

${ }^{43}$ Art 18(5).
} 
delegates". ${ }^{44}$ It goes on to say that if the delegates cannot reach an agreement on the matters, it should be referred to the governments of the contracting states for resolution. ${ }^{45}$

This provision provides no guidance to the governments as to what to do in the event that negotiations fail to reach a resolution. When a dispute arose under the Budapest Treaty the governments eventually agreed to take the matter to the ICJ. A discussion of the outcome in that case will feature in the following section which looks at the different ways in which states have chosen to deal with watercourse disputes in the past, and the varying levels of success of the mechanisms chosen.

\section{State Behaviour}

The foregoing discussion has demonstrated the range of options that states have available to them to resolve disputes concerning an international watercourse. The following section will explore the methods that states have used to settle watercourse related disputes in the past through briefly looking at a number of case studies. It will examine the general nature of the process, and provide information as to how the different mechanisms were used in practice and their effectiveness in resolving the matter.

\section{A. Negotiation}

Negotiation is normally the first method of dispute settlement employed by states when a dispute arises in any area of international relations. ${ }^{46}$ It is also often the only method employed, due to its high success rate at resolving disputes, both in the watercourse context, and generally. ${ }^{47}$

Due to most inter-state negotiations being conducted in private there are few records as to how negotiations have been used to resolve disputes. Information about a negotiation often only becomes available when it has been unsuccessful and the parties have progressed to a more public forum in an attempt to settle the matter. In light of this the following section will outline a

\footnotetext{
${ }^{44}$ Treaty Concerning the Construction and Operation of the Gabčíkovo-Nagymaros System of Locks, HungaryCzechoslovakia 1109 UNTS 236 (Signed 16 September 1977), art 27(1).

${ }^{45}$ Art 27(2).

${ }^{46}$ Merrils "The Means of Dispute Settlement", above n 3, at 535; Sarah Mateljan "Water Wars: Preventing and Resolving Conflicts over Transboundary Groundwater Resources" (2007) 14(2) Murdoch University eLaw Journal 178 at 207.

${ }^{47}$ John Collier and Vaughan Lowe The Settlement of Disputes in International Law (Oxford University Press, Oxford, UK, 1999) at 20; Mavommatis Palestine Concessions (Greece v Britain) (1924) PCIJ (series A) No 2; Mateljan, above n 46, at 207.
} 
number of features which make negotiations attractive to states seeking to resolve a dispute concerning an international watercourse.

\section{Benefits of the Negotiation Process}

Negotiations are engaged in as a first stage in dispute resolution for highly pragmatic reasons. ${ }^{48}$ Negotiations are generally more cost effective than other forms of dispute resolution and states are able to remain in control of the process, which is particularly important when the matter relates to a vital resource such as water. ${ }^{49}$

The control that states are able to have over the negotiation process is due to its inherent flexibility. ${ }^{50}$ This flexibility extends to nearly every area of the process including who must be present, when and where the negotiations will take place, and the nature of suggested resolutions. This flexibility is beneficial in this context as it allows the parties to take broader considerations into account, rather than having to come to a result based on strict legal principles. ${ }^{51}$

One particular way that states can benefit from this flexibility in the context of international watercourse disputes is through gaining the assistance of an expert in the field of watercourses. This person can advise the parties of the implications of a particular action on water flow and quality as well as the feasibility of suggested solutions to the dispute.

The other crucial feature of negotiations is that the process can be as public or as confidential as the parties choose. The ability to keep the details of the dispute and any possible resolution private is often an incentive for parties to engage in the process. ${ }^{52}$ Confidentiality can stop a matter escalating unnecessarily, and can be beneficial in that it does not create a public precedent for future disputes.

\footnotetext{
${ }^{48}$ See: Christine Gray and Benedict Kingsbury "Developments in Dispute Settlement: Inter-State Arbitration Since 1945" (1992) 63(1) The British Yearbook of International Law 98 at 100.

${ }^{49}$ Merrils International Dispute Settlement, above n 3, at 18; Palmer, above n 3, at 41.

${ }^{50}$ See: Collier and Lowe, above n 27, at $20-24$.

${ }^{51}$ At 24; L H Legault "The Roles of Law and Diplomacy in Dispute Resolution: The IJC as a Possible Model" (2000) 26 Canada-United States Law Journal 47 at 47.

${ }^{52}$ Attila Tanzi and Cesare Pitea "Emerging Trends in the Role of Non-State Actors in International Water Disputes" in The International Bureau of the Permanent Court of Arbitration (ed) Resolution of International Water Disputes (Kluwer Law International, The Hague, 2003) 259 at 262 .
} 


\section{B. Mediation and Good Offices}

In the event that tensions between states cause negotiations to be unfeasible, an independent third party may assist the parties in reaching a solution on the matter. A third party may also be useful in the event that negotiations reach a stalemate. This assistance can come from a mediator or good offices. This assistance can help to prevent the dispute proceeding to more costly binding forms of third party dispute resolution. ${ }^{53}$ However, this assistance requires the consent of the parties to the dispute and therefore states must be willing to move towards a resolution. ${ }^{54}$ The parties must also agree to any solution which is reached in the process. ${ }^{55}$

The 1907 Hague Peace Conference described the role of a mediator as one of "reconciling opposing claims and appeasing the feelings of resentment which may have arisen between the states at variance". ${ }^{56}$ This reflects the active role that a mediator takes in the settlement of disputes through gaining the opinions of both sides and putting forward their own suggestions as to how the matter can be resolved. ${ }^{57}$ This can be contrasted with the more restricted approach taken by those acting as good offices that assist the parties in coming to their own conclusion by acting as a go between. ${ }^{58}$ These roles can be beneficial as often parties may feel more comfortable making concessions through a third party, rather than directly to the other side. ${ }^{59}$

There has been some use of mediation in the international watercourse context, although the details are often only reported if it is unsuccessful and the matter proceeds to a more public forum. For example the European Commissioner attempted to help Hungary and Czechoslovakia resolve their dispute over the development of the Danube Dam. ${ }^{60}$ Mediation has also been used to assist states in reaching agreements to govern the management of their international watercourses. The Indus Waters Treaty is one example where mediation was used successfully in this way.

\footnotetext{
${ }^{53}$ Collier and Lowe, above n 47, at 27; Merrils "The Means of Dispute Settlement", above n 3, at 537.

${ }^{54}$ At 29.

${ }^{55}$ At 29.

${ }^{56}$ Convention for the Pacific Settlement of International Disputes (1907) 205 CTS 233, art 4.

${ }^{57}$ This can be contrasted with the role of good offices whose main task is to act as a conduit between the parties, relaying messages but not adding their own input. Salman M.A.Salman "Good Offices and Mediation and International Water Disputes in The International Bureau of the Permanent Court of Arbitration (ed) Resolution of International Water Disputes (Kluwer Law International, The Hague, 2003) 155 at 176; Collier and Lowe, above $\mathrm{n}$ 47 , at 27.

${ }^{58}$ Salman, above $\mathrm{n} 57$, at 176.

${ }^{59}$ At 199.

${ }^{60}$ Sergei Vinogradov, Patricia Wouters and Patricia Jones Transforming Potential Conflict into Cooperation Potential: The Role of International Water Law (UNESCO, Paris, 2003) at 29.
} 
Despite mediation not playing a large role in this context in the past S.M.A. Salman has argued that the use of good offices and mediation may grow in the future with an increasing trend among states towards cooperation and the amicable resolution of disputes over watercourses. ${ }^{61}$ The process has similar benefits to negotiation in that it is generally more cost effective and less time consuming than other processes of dispute resolution making it of value for states who want to settle the issue as quickly and efficiently as possible.

\section{Indus Waters Mediation}

The mediation conducted by the World Bank (WB) between India and Pakistan which lead to the Indus Waters Treaty is one of the most notable and successful examples of mediation being used in the context of international watercourses. ${ }^{62}$ The President of the WB, Eugene Black offered mediation services to India and Pakistan in the 1940s and 1950s in order for the states to formulate an agreement for the management of the Indus river system. This intervention occurred due to a fear "that the growing unease between India and Pakistan over water could be a potential flashpoint for war". 63

Although this role began as one of good offices, it developed into mediation after the WB began making suggestions to the parties as to how the agreement should be formulated. ${ }^{64}$ The WB was able to provide the parties with the technical assistance and the required resources to formulate a management plan that gave each state an equitable share of the resource. The role played by the WB in this case has helped to limit the disputes between the states in the following years through providing for the resolution of disputes by the PIC.

\section{Joint Commissions}

The creation of a joint commission was one of the key aspects of the dispute resolution process in the Indus Water Treaty. Although the UN Convention discusses the use of joint commissions as process to be engaged in when direct negotiations fail, many treaties, including the Indus

\footnotetext{
${ }^{61}$ Salman, above n 57, at 198-9.

${ }^{62}$ At 177.

${ }^{63}$ G.T. Keith Pitman "The Role of the World Bank in Enhancing Cooperation and Resolving Conflict on International Watercourses: The Case of the Indus Basin" in M.A. Salman and Laurence Boisson de Chazournes (eds) International Watercourses: Enhancing Cooperation and Managing Conflict (World Bank Technical Paper No. 414, 1998) 155 at 160; D. E. Lilenthal “Another Korea in the Making?" Collier's (United States, 4 August 1951).

${ }^{64}$ See: Salman, above n 57, at 183-196.
} 
Waters Treaty, provide them as a first option to be engaged with when a disagreement or question arises between the co-riparian states.

A joint commission has a number of roles. They are often in charge of overseeing the management and development of a particular watercourse. In order to do this effectively the joint commission enables regular and ongoing communication between the states concerned. ${ }^{65}$ This communication is generally on a practical day-to-day management level, rather than through political actors. This allows for the interaction of multiple departments and organisations that have a stake in the resource. ${ }^{66}$

The day-to-day management role of the joint commission means they are often in the best position to deal with disputes relating to the watercourse. This is because they have a good understanding of the practical implications of any development and can advise on how any negative consequences may be limited. This practical advice can allow for a quick resolution of the matter before it becomes an intense dispute.

The dispute resolution role of the joint commission is aided by the fact that commissioners generally have competence in both the technical and policy aspects of the watercourse's operation. The body is normally made up of an equal number of commissioners from each state concerned, and decisions within the body usually require a majority vote. ${ }^{67}$ Majority voting requires the representatives from each side to be in agreement before the matter can progress. This allows the joint commission to assist in both the avoidance and settlement of disputes.

\section{Joint Commissions in Practice}

Most joint commissions have had a high success rate for resolving disputes at an early stage. However, some regions appear to have more success with joint institutions than others. Joint institutions in Asia and North America appear to have a higher capacity to deal with disputes than those in Europe and Africa. In the latter two regions states appear to be more willing to submit disputes to more independent forms of dispute settlement like arbitration and adjudication. ${ }^{68}$ In light of this the two examples in the following section are from North America

\footnotetext{
${ }^{65}$ Eric Mostert Conflict and Co-operation in the Management of International Freshwater Resources: A Global Review (UNESCO, Paris, 2003) at 24.

66 Susan J Buck, Gregory W. Gleason, and Mitchel S. Jofuku "The Institutional Imperative: Resolving Transboundary Water Conflict in Arid Agricultural Regions of the United States and the Commonwealth of Independent States" (1993) 33(3) Natural Resources Journal 595 at 602.

${ }^{67}$ Collier and Lowe, above n 47, at 22.

${ }^{68}$ Vinogradov, Wouters and Jones, above n 60, at 66.
} 
and Asia, respectively. However, this does not mean that institutions in other areas cannot be effectively implemented.

(a) International Joint Commission

The International Joint Commission (IJC) was established between the United States of America and Canada as part of the Boundary Waters Treaty 1909. ${ }^{69}$ The IJC is composed of three commissioners from either state, who are independent from their respective governments. The IJC has a range of roles in managing the relationship between the states, including approving requests to obstruct or divert waters that flow across the border between the two countries and answering requests put forward by states as to the nature of their rights under the Treaty. Depending on the nature of the question the IJC's response can be binding or merely advisory. ${ }^{70}$

The IJC has had a good success rate in resolving the matters that have arisen during its 100 year history, with no issues having to go further than the body to date. This represents a success in one of the main aims of the treaty, which was to "prevent disputes regarding the use of boundary waters". 71

One notable success of the IJC was the inquiry into the impact of a coal mine at Cabin Creek on a tributary to the Flathead River, which flows from British Columbia in Canada into Montana in the United States. ${ }^{72}$ In 1980 a Canadian company proposed to start mining in the upper area of the Flathead River causing concern about the impact of the proposed mining on the quality of the water in the river among those in the United States. ${ }^{73}$ The IJC was asked by the parties to investigate the impact that the mine would have in order to determine if it was compliant with the Boundary Waters Treaty. The IJC established a study board to undertake a technical assessment of the project and its implications. ${ }^{74}$ The process undertaken by the study board was in effect a process of fact finding, which will be discussed subsequently in this paper. The board made recommendations to the IJC, which were in turn handed to the parties. This included advising the Canadian company that the mines operation would violate the terms of the

\footnotetext{
${ }^{69}$ Treaty Between Great Britain and the United States Relating to Boundary Waters and Boundary Questions 208 CTS 213 (Signed 11 January 1909), art VII.

${ }^{70}$ See: Art VIII-X.

71 "Editorial Comment" (1912) 6(1) American Journal of International Law 149 at 191.

72 Stephen C McCaffery Sixth Report on the law of the non-navigational uses of international watercourses A/CN.4/427 (1990) at [60].

${ }^{73}$ Vinogradov, Wouters and Jones, above n 60, at 30.

${ }^{74}$ At 30 .
} 
Boundary Waters Treaty. ${ }^{75}$ Despite the ICJ's recommendations being merely advisory the states followed their advice and abandoned the project. ${ }^{76}$

A number of conclusions can be drawn from this outcome. Firstly, it shows the respected and neutral position that joint commissions can take. They objectively examine the facts, and even if the recommendations are only advisory they are likely to be followed by the states concerned. ${ }^{77}$ Secondly, it demonstrates the importance of understanding the implications of any proposed project. The IJC had experts look into the plans, and examine their potential effects. A decision was unlikely to have been reached without this being undertaken.

(b) Permanent Indus Commission

One of the most prominent and often lauded as the most successful joint commission is the PIC, established by India and Pakistan in the Indus Waters Treaty of 1960, discussed above. The PIC was created to "establish and maintain the cooperative arrangements" in the Indus Waters Treaty. ${ }^{78}$ The PIC is composed of one commissioner from each state, both of whom have the ability to bind their respective governments in decisions falling within the Treaty. ${ }^{79}$ This gives the decisions of the PIC an element of authority which is not shared by the IJC. The higher authority given to the commissioners in the PIC is likely to be because of the tense relationship between India and Pakistan which limits the willingness of the governments to interact in the same way that the United States and Canada do with the IJC.

The PIC has been able to resolve most matters put to it in the half century since its formation. This is despite the high levels of political tension between India and Pakistan during the period, including two wars. ${ }^{80}$ The continued efficient functioning of this body demonstrates that high level political cooperation is not necessary for a joint commission to be successful. ${ }^{81}$

\footnotetext{
${ }^{75}$ McCaffery, above $\mathrm{n} 72$, at [61].

${ }^{76}$ Legault, above n 51, at 53.

77 The success of joint commissions in this field has been demonstrated through the history of the IJC and PIC. These body's have the knowledge, experience and a more detached or impartial approach which can assist the parties in resolving the dispute. The expertise of the joint commission is generally well respected by the parties it is acting for. McCaffery, above $\mathrm{n}$ 72, at [42]; J Evensen First Report on the law of the non-navigational uses of international watercourses A/CN.4/367 and Corr.1(1983) at [209].

${ }^{78}$ Indus Waters Kishengana (Pakistan v India) (Partial Award) PCA 18 February 2013 at [139] [Indus Waters].

${ }^{79}$ Indus Waters Treaty, above $n$ 39, art VIII.

${ }^{80}$ Phillip R. Trimble "International Institutions and the World's Water" (1996) 90 American Society of International Law Proceedings 499 at 501.

${ }^{81}$ Another example of this is the Committee setup to help oversee the management of the Mekong River. It has continued to function despite "intense political disputes between the riparian countries." Aaron T. Wolf
} 
The first occasion on which the PIC was unable to resolve the matter put to it was in the case of the development of the Kishenganga Hydro Electricity Project. The disagreement over the developments legitimacy was put to the Commission in 2004, 2005 and again in 2009 but a settlement was unable to be reached on any of these occasions. This resulted in the Indus Waters Kishenganga Arbitration (Indus Waters) which will be discussed in a subsequent section of this paper. Although the PIC was unable to find a resolution for this matter themselves they encouraged the parties to continue to pursue peaceful means of dispute settlement. This example demonstrates that even if a joint commission is unable to find an acceptable resolution, it can be helpful in guiding the parties further through a dispute resolution process.

\section{International Court of Justice}

In situations where the states concerned are unable to resolve their dispute directly, an external body can be used to provide the states with a solution. The ICJ is one such independent adjudicative body which has been made use of in this area. Although recourse to the ICJ is provided for in the UN Convention and other individualised treaties, the consent of both states is required before the ICJ has jurisdiction to hear the matter. ${ }^{82}$

\section{Practical Experiences with the ICJ}

The following section will examine watercourse related disputes heard by both the ICJ, and its predecessor the Permanent Court of International Justice (PCIJ). ${ }^{83}$ There is a large range of information available on these matters as the ICJ is a public forum. ${ }^{84}$ Although these cases have produced mixed results in terms of their success at resolving these kinds of disputes they illustrate some of the important features of the ICJ which are of particular value in the context of international watercourses.

\footnotetext{
"International Water Conflict Resolution: Lessons from Comparative Analysis" (1997) 13(3) International Journal of Water Resources Development 333 at 349.

${ }^{82}$ See: Statute of the International Court of Justice, art 36; Andreas Zimmermann, Christian Tomuschat, Karin Oellers-Frahm and Christian J. Tams (eds) The Statute of the International Court of Justice: A Commentary (2 ${ }^{\text {nd }}$ ed, Oxford University Press, Oxford, UK, 2012) at 660-691.

${ }^{83}$ Merrils International Dispute Settlement, above n 3, at 127.

${ }^{84}$ Under the Statute of the International Court of Justice there is a presumption in article 46 that the hearings of the court will be public. The states involved may demand that the public is not admitted to these proceedings, but this provision is not used often. Statute of the International Court of Justice, art 46; Zimmermann, Tomuschat, OellersFrahm and Tams, above n 82, at $1197-1206$.
} 


\section{(a) Diversion of Water from the River Meuse}

The Meuse is a river which forms a large part of the border between Belgium and the Netherlands; although in places it runs entirely within the territory of the Netherlands. ${ }^{85}$ One of the main uses of the river is to feed the numerous canals which are used for navigation in the region. ${ }^{86}$ Belgium and the Netherlands had been making use of water for this purpose for some time, and a Treaty agreed to in 1863 provided guidelines for where the required water should be drawn from and limits on such drawing. ${ }^{87}$

After the First World War the canals provided for in the 1863 Treaty were insufficient for the growing navigation needs of both countries. As a result both countries began the construction of new systems of canals and locks in their territory, fed with water from the Meuse. ${ }^{88}$ Although the new canals were not drawing water from the same points set out in the 1863 Treaty, neither state thought the other had the right to increase the total quantity of water they were drawing from the Meuse under the terms of the 1863 Treaty. Belgium and the Netherlands attempted to reach an agreement to allow each project to continue, but this could not be achieved.

As a result of the negotiations failing the Netherlands filed an application with the PCIJ in August $1936 .^{89}$ Their claim alleged that Belgium had breached the terms of the 1863 Treaty by exceeding the drawing limits. This was met with a counterclaim from Belgium alleging that the Netherlands had also drawn more than its allowance of water under the 1863 Treaty. ${ }^{90}$ The PCIJ heard the parties' arguments in May 1937, and released its decision in June. ${ }^{91}$ This is one of the faster responses from an international judicial body.

The majority of the Court rejected the arguments of both states, finding that the actions of neither state breached the conditions of the 1863 Treaty. The Court considered that both states were able to do what they wanted within their own territory so long as it did not impact the specific volumes of water that certain intakes were not allowed to breach under the Treaty. ${ }^{92}$ As a result

\footnotetext{
${ }^{85}$ Diversion of Water from the Meuse (Netherlands $v$ Belgium) (1937) PCIJ (series A/b) No 70 at [17] [Diversion of Water from the Meuse].

${ }^{86}$ At [18].

${ }^{87}$ See: Treaties of Commerce and Navigation, For the Regulation of Drawing s of Water from the Meuse and for the Extinction of the Scheldt Tolls between Belgium and the Netherlands 127 CTS 435 (Signed 12 May 1863).

${ }^{88}$ Diversion of Water from the Meuse, above $\mathrm{n} 85$, at [40] - [47].

${ }^{89}$ Both states recognised the jurisdiction of the court. At [1], [47].

${ }^{90}$ At [48].

${ }^{91}$ At [11], [130].

${ }^{92}$ At [91].
} 
of the judgment both countries continued in the development of their canal systems, increasing the amount of water drawn from the Meuse.

The decision can be viewed as a success as it provided an end to the dispute. However the matter re-emerged in the 1990s when issues around conservation of the Meuse came to the fore. This time the states were able to negotiate an agreement. The agreement was entered into between Belgium, the Netherlands and France in 1994. The Agreement on the Protection of the River Meuse aimed to "preserve and improve the quality of the Meuse" by keeping in mind the parties' common interests. ${ }^{93}$ The agreement also established the International Commission for Protection of the Meuse to protect the river against pollution. This provided "a forum for the exchange of information on projects ... that have a significant trans-boundary impact on the quality of the Meuse". ${ }^{94}$ This body operates essentially as a joint commission and is likely to impact the way that disputes are dealt with in relation to the Meuse in the future. The willingness of the states to enter this agreement, and establish this kind of body, may reflect the past experience they had with the PCIJ and a desire to try to avoid engaging with the institution in the future.

\section{(b) Case Concerning the Gabčikovo-Nagymaros Project}

In contrast to the previous case the Gabčikovo-Nagymaros Project (Gabčikovo-Nagymaros) case is a well-known example of where the ICJ's decision has not provided the parties with a solution to the matter before the Court. The dispute arose out of the Budapest Treaty, discussed above at IV, under which the parties agreed to develop a system of locks on the Danube River as a joint investment. $^{95}$

Work began on the project in 1978, and proceeded largely unhindered until $1989 .{ }^{96}$ In 1989 , due to public criticism relating to the adverse environmental impacts of the project, Hungary suspended their share of the works, later choosing to abandon them completely. ${ }^{97}$ A negotiated settlement was attempted in light of this, but when Czechoslovakia realised that Hungary was not interested in recommencing their role in the project it developed an alternative of its own. ${ }^{98}$ This project, known as 'Variant C', sought to dam the Danube River and cut off the water flow into

\footnotetext{
${ }^{93}$ Vinogradov, Wouters and Jones, above n 60, at 39.

94 At 39.

95 Treaty Concerning the Construction and Operation of the Gabčíkovo-Nagymaros System of Locks, HungaryCzechoslovakia, above n 44; Gabčikovo-Nagymaros Project (Hungary v Slovakia) [1997] ICJ Rep 7 at [15], [20] [Gabčikovo-Nagymaros].

96 There was an agreement to slow work down in 1983 and an agreement to accelerate it in 1989. At [21].

97 At [22], [32].

${ }^{98}$ At [32] - [38].
} 
Hungary. During this period Czechoslovakia separated into Slovakia and the Czech Republic. The development was within the territory of the new Slovakia and they moved to implement the plan with preparatory works which caused the dispute to escalate. ${ }^{99}$

The Budapest Treaty contained some provisions for the resolution of disputes between the parties, which are outlined in section IV. The parties followed this process through to its conclusion, first letting the matter be handled by government delegates, then negotiating directly with some assistance from the European Commissioner. However, neither of these processes resulted in a resolution being reached. ${ }^{100}$

As the Treaty provided no further process for dispute settlement the parties agreed, through a special agreement, to allow the ICJ to hear the matter. ${ }^{101}$ The matter was submitted to the ICJ on 2 July 1993 but hearings were not held until in March and April 1997. ${ }^{102}$ During the period that the hearings were held the bench made visits to the sites concerned, demonstrating the ICJ's ability to alter its procedure in light of the matter before it. ${ }^{103}$ Later that year the Court's decision was released. This delay highlights the often time-consuming nature of ICJ proceedings. ${ }^{104}$

The ICJ found that both parties had violated their treaty obligations, through Hungary's termination of the treaty and Slovakia's unilateral implementation of 'Variant C'. ${ }^{105}$ Although these violations would generally entitle the other state to compensation, as both parties committed wrongs the ICJ held no compensation would be payable. ${ }^{106}$

Despite both parties failing to uphold their obligations, the ICJ found the Budapest Treaty was still in force. ${ }^{107}$ The Court concluded that the parties should resume negotiations in order to implement the project, in light of the altered circumstances. ${ }^{108}$ The Court indicated that the

${ }^{99}$ See: at [23].

${ }^{100}$ At [24].

${ }^{101}$ A special agreement is only one way in which parties to a dispute can submit to the jurisdiction of the court. See: Statute of the International Court of Justice, art 36. This special agreement was reached through mediation facilitated by the Common of the European Communities. Gabčikovo-Nagymaros, above n 95, at [24], [25].

${ }^{102}$ At [10].

${ }^{103}$ At [10].

${ }^{104}$ Anna Spain “Integration Matters: Rethinking the Architecture of International Dispute Resolution” (2010) 32 University of Pennsylvania Journal of International Law 1 at 18.

${ }^{105}$ For Courts reasoning see: Gabčikovo-Nagymaros, above n 95, at [54] - [88].

${ }^{106}$ At [153].

${ }^{107}$ At [114], [133].

${ }^{108}$ This included the changes in environmental knowledge. At [140], [141]. 
success of these talks may be aided by the assistance of a third party such as the European Commissioner, due to the parties' opposition to altering their positions. ${ }^{109}$

On the basis of the special agreement it appears that the ICJ had scope to provide the states with a more practical result. Article 2(2) of that agreement provides that the Court is to determine the legal consequences, including the parties' rights and obligations, arising from its judgment. ${ }^{110}$ The fact that the Court merely directed the parties to negotiate, rather than give any detail as to the rights and obligations moving forward demonstrates one of the pitfalls of adjudication in this context.

Decisions such as this are not unique to this case. Referring parties back to negotiations is common to judgments relating to shared resources more generally. ${ }^{11}$ There may be a number of reasons for the Court to make decisions of this kind, including that they believe that the parties are more likely to adhere to an agreement if they reach it themselves. The fact that these decisions do not to provide extra guidance may also reflect the fact that the bench of the ICJ is made up of experts in the field of international law, rather than experts in the operation of a watercourse. Therefore the Court may not hold the requisite knowledge to provide a practical solution to the dispute, although they can enlist expert assistance in order to overcome this. ${ }^{112}$

Hungary and Czechoslovakia have continued to negotiate since the judgment, but no resolution has been reached to date. ${ }^{113}$ A framework agreement was drafted shortly after the ICJ's decision, but this was not accepted by the Hungarian government. ${ }^{114}$ In light of this failure in negotiations Slovakia made an application to the court on 3 September 1998 requesting an additional judgement. ${ }^{115}$ This request was in accordance with the provision in the special agreement, that if there was no agreement between the states within six months the parties could submit the matter

\footnotetext{
${ }^{109}$ At [143].

110 Special Agreement for submission to the International Court of Justice of the differences concerning the Gabcikovo-Nagymaros Project 1725 UNTS 226 (Signed 7 April 1993), art 2(2).

${ }^{111}$ Collier and Lowe, above n 47, at 22. See: North Sea Continental Self (Germany v Denmark) [1969] ICJ Rep 3; Fisheries Jurisdiction Case (United Kingdom v Iceland) [1974] ICJ Rep 3.

${ }^{112}$ Statute of the International Court of Justice, art 50. Although the court only rarely makes use of these powers, instead preferring to use the expert evidence provided by the parties. See: Zimmermann, Tomuschat, Oellers-Frahm and Tams, above $\mathrm{n} 82$, at $1287-1299$.

${ }^{113}$ Vinogradov, Wouters and Jones, above n 60, at 43.

114 International Court of Justice "Gabčíkovo-Nagymaros Project (Hungary/Slovakia): Hungary to file by 7 December 1998 a written statement of its position on Slovakia's request for an additional Judgment” (press release, 7 October 1998).

${ }^{115}$ International Court of Justice, above n 114.
} 
back to the court to "determine the modalities of executing the judgment". ${ }^{116}$ However, this application has not proceeded any further and the case remains categorised as pending before the ICJ.

\section{(c) Pulp Mills on the River Uruguay}

A similar decision to that provided in Gabčlkovo-Nagymaros was seen in the most recent decision from the ICJ in this context, Pulp Mills on the River Uruguay. The River Uruguay forms the border between Argentina and Uruguay and it is governed by the Statute of the River Uruguay 1975. ${ }^{117}$ This Treaty created an Administrative Commission for the River (CARU), whose role involved facilitating cooperation and communication between the parties as well as resolving disputes between the parties if they arose. ${ }^{118}$

During 2002 and 2003 a number of companies applied to the government of Uruguay to obtain consent to construct pulp mills along the banks of the River Uruguay. ${ }^{119}$ Uruguay informed CARU of these requests, as it was required to do under Article 7 of the 1975 Treaty, and meetings were held in order to obtain the CARU's consent to the developments. On the basis of CARU's consent, Uruguay provided the companies with permits to begin the construction of two pulp mills. ${ }^{120}$

However, Argentina claimed that the construction of the two planned pulp mills on the River would breach Uruguay's obligations under the 1975 Treaty. The relevant Ministers of Argentina and Uruguay held meetings to address these concerns in early 2005. These negotiations were unable to find a solution that both parties were satisfied with. ${ }^{121}$

The failure of the negotiations resulted in Argentina instituting proceedings against Uruguay at the ICJ on May 42006 in accordance with Article 6 of the 1975 Treaty. ${ }^{122}$ This provides that if no resolution can be reached by CARU or direct negotiations between the states, within 180 days then either party may submit the matter to the ICJ for determination. ${ }^{123}$

\footnotetext{
${ }^{116}$ Special Agreement, above n 110, art 5(3).

${ }^{117}$ Pulp Mills on the River Uruguay (Argentina v Uruguay) [2010] ICJ 14 at [26], [27] [Pulp Mills].

${ }^{118}$ At [90], [92].

119 At [29], [37].

${ }^{120}$ Later, as a result of this dispute one of those projects was abandoned. At [36].

121 At [40].

${ }^{122}$ At [1].

${ }^{123}$ Statute of the River Uruguay, Uruguay-Argentina 1295 UNTS 340 (Signed 26 February 1975).
} 
There were a number of requests by both states for the Court to order provisional measures to protect the status quo while the matter was being heard. ${ }^{124}$ Provisional measures can be used by the Court at its discretion to protect the interests of a party while a case is being heard. ${ }^{125}$ In this case the applications were all rejected as the Court did not feel that the measures were required in the circumstances. ${ }^{126}$ This meant that the construction of the mill continued, and it became operational in 2007.

In the case before the ICJ Argentina alleged that Uruguay failed to comply both procedurally and substantively with the provisions in the 1975 Treaty. In its judgment in April 2010 the Court found that Uruguay had breached its procedural obligations in that it failed to provide CARU with sufficient information to allow them to assess the potential impact of the development. ${ }^{127}$ However the Court found that there was not sufficient evidence to show that Uruguay had breached its substantive obligations by failing to undertake appropriate environmental assessments and exceeding the pollution limits in the river.

In light of the Court's findings Argentina requested they make number of orders. These included that the mills be dismantled, compensation be paid and Uruguay guarantee they will not breach the 1975 Treaty again. ${ }^{128}$ Although the ICJ has the power to make orders of this nature, it did not think that they were appropriate in the circumstances. ${ }^{129}$ The Court instead encouraged the parties to cooperate in order to manage the future of the river in a way that did not lead to the need for judicial settlement of disputes. ${ }^{130}$ As a result of this decision the parties were left to negotiate, despite requesting that the matter to be settled by the Court. This was a similar outcome to that in the Gabčlkovo-Nagymaros case.

Argentina and Uruguay continued negotiations in light of the Court's decision and an agreement was reached between the states in August 2010. This agreement provides for monitoring of the

\footnotetext{
${ }^{124}$ Pulp Mills, above n 117, at [8]-[13].

${ }^{125}$ Statute of the International Court of Justice, art 41. Interim measures have been held to be enforceable against a state See: LaGrand (France v United States of America) [2001] ICJ Rep 466. For more information on the courts approach to interim measures see: Zimmermann, Tomuschat, Oellers-Frahm and Tams, above n 82, at 1029 - 1073.

${ }^{126}$ Pulp Mills, above n 117, at [8] - [13].

127 They also failed to provide them additional information when requested. At [106].

${ }^{128}$ At [276], [277].

${ }^{129}$ At [275] - [277].

${ }^{130}$ At [281].
} 
river to ensure that the quality of the water is not impacted by the operation of the pulp mill. ${ }^{131}$ This arrangement is to be overseen by CARU. ${ }^{132}$ This outcome appears a lot more positive than that in the Gabčkovo-Nagymaros case, but it will take time to see if the parties are able to effectively manage the new arrangements or whether further disputes will arise in the future. One factor that may have influenced the more positive outcome in this case is the fact that the relationship between Argentina and Uruguay was not under the same level of strain that the relationship between Hungary and Slovakia was when the Gabčikovo-Nagymaros decision was made. The changing political circumstances in Eastern Europe at the time of the dispute were likely to have had a large impact on the interaction between the states. This was not a factor in this case making it easier for the states to reach a negotiated resolution on the basis of the courts direction.

(d) Pending Matters

Along with the decided cases, there are also a number of cases in this area waiting to be heard by the ICJ demonstrating states' continued support of this institution. Certain Activities carried out by Nicaragua in the Border Area (Costa Rica v Nicaragua) and Construction of a Road in Costa Rica along the San Juan River (Nicaragua v Costa Rica) both relate to activities on the San Juan River which runs along the border between the two South American countries.

The first application was made by Costa Rica in November 2010, relating to activities undertaken along the bed of the San Juan River by Nicaragua in the course of the construction of a canal. ${ }^{133}$ The Court has issued provisional measures in order to stop further environmental damage before it renders its decision. ${ }^{134}$

The second application was filed by Nicaragua in December 2011 after Costa Rica began to construct a road adjacent to the San Juan River. ${ }^{135}$ Nicaragua alleges that this development will

\footnotetext{
131 "Uruguay/Argentina implement the end of the pulp mill dispute" MercoPress (Online ed, Montedideo, Uruguay, 31 August 2010); “Argentina and Uruguay settle seven-year pulp mill row” BBC (Online ed, London, 16 November 2010).

132 "Uruguay/Argentina implement the end of the pulp mill dispute", above n 131; "Argentina and Uruguay settle seven-year pulp mill row"; above n 131.

${ }^{133}$ See: Certain Activities Carried Out by Nicaragua in the Border Area (Costa Rica v Nicaragua) (Application Instituting Proceedings) (International Court of Justice, General List Number 150, 18 November 2010).

${ }^{134}$ Certain Activities Carried Out by Nicaragua in the Border Area (Costa Rica v Nicaragua) (Provisional Measures) [2011] ICJ Rep 6.

${ }^{135}$ Construction of a Road in Costa Rica Along the San Juan River (Nicaragua v Costa Rica) (Application Instituting Proceedings) (International Court of Justice, General List Number 152, 22 December 2011).
} 
cause environmental damage to the river and detrimentally affect their interest in it. $^{136}$ In mid2013 no interim measures had been issued, despite applications being made, highlighting once again the lengthy nature of the ICJ process.

\section{E. Arbitration}

Arbitration has a long history in the settlement of inter-state disputes, one that is too lengthy to be explored in any detail in this paper. ${ }^{137}$ Suffice to say that the modern incarnation of arbitration, with reasoned awards, has been visible since the end of the 19th century. ${ }^{138}$

Arbitration has been used to resolve many disputes over history, relating to rivers, especially in relation to the delimitation of boundaries and navigational issues. ${ }^{139}$ Although it has also been used in matters relating to the development of a watercourse this has not occurred as frequently. This may be because inter-state arbitration has been somewhat declining in popularity since the end of World War Two which was when development issues began to come to the fore. ${ }^{140}$ However arbitration has been included in most of the present day watercourse agreements, including the UN Convention and individual treaties, "either as an optional mechanism ... or as a

compulsory procedure for disputes that the parties have failed to resolve by other means". ${ }^{141}$ Due to its prominence as a tool for the resolution of disputes in this context, it is likely to be increasingly relied on to resolve development-related disputes in the future.

\section{Practical Experience with Arbitration}

The following section provides an overview of the two key development related cases that have come before arbitral tribunals. The length of time between the cases demonstrates how little arbitration has been used in this area by states.

\footnotetext{
136 At 4.

${ }^{137}$ For more information on arbitration see: Merrils International Dispute Settlement, above n 3, at 91; Collier and Lowe, above n 47, at 31, Alina Kaczorowska Public International Law ( ${ }^{\text {rd }}$ ed, Routledge-Cavendish, Oxon, UK, 2005) at 370; Merrils “The Means of Dispute Settlement”, above n 3, at 542.

${ }^{138}$ See: Collier and Lowe, above n 47, at 32.

${ }^{139}$ See: Award in Regard to the Validity of the Treaty of Limits between Costa Rica and Nicaragua (Costa Rica $v$ Nicaragua) (1888) 28 RIAA 189; Kushk River (Great Britain (Afghanistan) v Russia) Anglo-Russian Commission 22 August 1893; Tacna-Arica Question (Chile v Peru) (1925) 2 RIAA 921.

${ }^{140}$ Gray and Kingsbury, above n 48, at 99.

${ }^{141}$ Vinogradov, Wouters and Jones, above n 60, at 32.
} 


\section{(a) Lake Lanoux}

This case arose when a French company requested a concession from the French government to divert waters off Lake Lanoux in order to generate hydro-electricity. ${ }^{142}$ Lake Lanoux is located in the Pyrennes in France and feeds the River Carol which flows through France and into Spain. The use of the waters in the region was governed by the Treaty of Bayonne 1866.

The original proposal put forward by France limited the amount of water that would be returned to the river after the diversion to the amount that was required to fulfil the needs of the Spanish people. ${ }^{143}$ However, after Spain voiced their opposition to the approach France amended the proposal so that all water diverted from the river would be replaced via an underground tunnel before it crossed into Spanish territory. ${ }^{144}$

Despite the change in proposal to alleviate Spanish concerns, Spain remained opposed as the diversions would give France the ability to cut off the water supply to Spain. In an attempt to stop the project progressing Spain requested that the Mixed Commission of Engineers established under the Treaty of Bayonne investigate the project. ${ }^{145}$ The Mixed Commission was set up in order to ensure that its terms of the Treaty were complied with. Even though the project was found to be compliant with the terms of the Treaty, Spain still maintained its opposition and a compromise was unable to be reached as to how the project should proceed. ${ }^{146}$

Despite this France continued with the development, which caused Spain to take the matter to an arbitral tribunal in November 1956 arguing that the project was in breach of the Treaty of Bayonne. ${ }^{147}$ Spain asked the Tribunal to declare that France should discontinue the construction of the works if no agreement could be reached between the two governments as to how to proceed. $^{148}$

The Tribunal rendered its award a year later, in November 1957. They held that France was able to undertake the project in its present form without breaching its obligations under the Treaty of

\footnotetext{
${ }^{142}$ Lake Lanoux (France v Spain) (1957) 24 ILR 101 at 105 [Lake Lanoux].

${ }^{143}$ Under the Treaty of Bayonne which governed the relationship, France was only required to return the quantity of water which corresponded to the needs of Spanish users. At 105-6.

144 At $105-6$.

${ }^{145}$ At 106-7.

146 At 108 .

${ }^{147}$ Consent was given as the result of a compromis between the two states.

148 At 108 .
} 
Bayonne, or any other principle of international law. ${ }^{149}$ As all the diversions would take place within French territory, and all water was to be restored before the river entered Spain, Spain would suffer no harm. ${ }^{150}$ There were no requirements in the Treaty which required the other state to consent to this type of project. ${ }^{151}$

They noted that there was no principle of international law which prevented a state from putting itself in a position where it could cause harm to another state. ${ }^{152}$ This position is arguably not true anymore, as will be seen from the Indus Waters case where the Tribunal has held that a minimum flow of water must be maintained in the river. This was to protect the interests of the lower riparian state by ensuring that the upper riparian state did not have the ability to cut off the water flow.

After the Tribunals decision France proceeded with the development of the hydro-electric facility and the water was diverted from the river as a result. France and Spain entered an agreement in 1958 to ensure that all water removed from the river would be restored before the river flowed into Spain. This agreement remains in force and there have been no further disputes about the matter. $^{153}$

\section{(b) Indus Waters Kishengana Arbitration}

The Indus Waters case is the most recent arbitral decision in this context, with only a partial decision having been released to date. Despite this case being recent, the allocation of the water in the Indus River Basin and its tributaries has long been a source of conflict between India and Pakistan.

An agreement relating to the management of the rivers was reached in 1960 with extensive support and assistance from the WB. The Indus Waters Treaty provided that the Western Rivers in the region were to be under Pakistani control, and the Eastern Rivers under Indian control. ${ }^{154}$ However, under the terms of the Treaty India was given a right to use the Western Rivers in its

\footnotetext{
${ }^{149}$ At 116.

${ }^{150}$ At $116,119$.

${ }^{151}$ At 126

${ }^{152}$ At 122.

${ }^{153}$ Agreement Between the Government of the French Republic and the Spanish Government Relating to Lake Lanoux 796 UNTS 235 (Signed July 12 1958); This was amended by an exchange of letters in 1970, Exchange of Letters Constituting an Agreement Between France and Spain Amending the Arrangement of 12 July 1958 Relating to Lake Lanoux 796 UTS 240 (Entered into Force 27 January 1970).

${ }^{154}$ Indus Waters Treaty, above n 39, art 2, 3.
} 
territory so long as they did not impact Pakistan's existing agricultural or hydro-electric uses. ${ }^{155}$ The dispute in this case related to India's right to use the Western Rivers.

India sought to develop the Kishengana Hydro-Electric Project (KHEP) on a tributary of a Western River. ${ }^{156}$ Pakistan disputed the legality of this development from the outset, arguing that it would affect their own proposal for a power station, which was to be located further downstream. ${ }^{157}$

The parties followed the process for dispute resolution set out in the Indus Waters Treaty, outlined in section IV, by first submitting the dispute to the PIC in 2004 and 2005. ${ }^{158}$ The PIC was unable to come to an agreement as to how to resolve the matter. ${ }^{159}$ As a result some reconfiguration was under taken by India in an attempt to make the design more acceptable to Pakistan. The matter was put back before the PIC by Pakistan in 2009 where they were again unable to reach a resolution. ${ }^{160}$ This was the first matter that the PIC has been unable to resolve since its inception in 1960.

As the PIC was unable to resolve the dispute Pakistan attempted to negotiate with India in accordance with the terms of the Indus Waters Treaty. ${ }^{161}$ However, India refused to cooperate. ${ }^{162}$ The lack of direct negotiations between the governments reflects the high levels of political tensions between the states.

As the matter found no resolution through negotiation, Pakistan chose to submit it to arbitration in May 2010. ${ }^{163}$ This is the next step provided in the Treaty, and one that does not require the consent of the other state under the terms of the Treaty. ${ }^{164}$ Each state appointed two members of the tribunal and the final three members were appointed by industry experts. These industry experts were "the Secretary-General of the United Nations (for selection of the Chairman), the Rector of the Imperial College of Science and Technology, London, England (for selection of the

${ }^{155}$ Art 3.

${ }^{156}$ Indus Waters, above n 78, at [128], [129].

${ }^{157}$ At [141] - [145].

${ }^{158}$ Indus Waters Treaty, above n 39, art 18(1).

${ }^{159}$ Indus Waters, above $\mathrm{n} 78$, at [146].

${ }^{160}$ At [148] - [151].

${ }^{161}$ Indus Waters Treaty, above n 39, art 18(4).

${ }^{162}$ Indus Waters, above n 78, at [152].

${ }^{163}$ At [4].

164 The treaty provides that where one party refuses to negotiate the other can unilaterally establish a Court of Arbitration to resolve the matter. Indus Waters Treaty, above n 39, art 18(5). 
Engineer Member), and the Lord Chief Justice of England (for selection of the Legal Member)". 165

The ability of the parties to a dispute to appoint the members of the tribunal is one of the key benefits of using arbitration compared to the ICJ. This feature allows parties to ensure that the people entrusted with resolving the dispute have the requisite knowledge in order to do come to the most practical and acceptable solution for the parties.

The tribunal process began with the order of proceedings being set in December 2011. This was followed by the parties exchanging pleadings. ${ }^{166}$ The process culminated with a hearing on the merits in August 2012. ${ }^{167}$ In conjunction with these hearings the tribunal visited the relevant sites in both India and Pakistan to assess the situation themselves. ${ }^{168}$ The hearings were conducted in private, in accordance with arbitrations default setting of confidentiality. ${ }^{169}$ However, the final reports of the tribunal have been made public with the consent of the states. ${ }^{170}$

In its partial decision, released in February 2013, the tribunal held that India was justified in constructing the KHEP as its project was underway before Pakistan's. ${ }^{171}$ However they held that India would have to ensure a minimum level of water continued to flow into Pakistan. ${ }^{172}$ This minimum flow is to be determined in the tribunal's final decision, expected in late $2013 .{ }^{173}$ They also held that India was not able to use the drawdown flushing technique to remove sediment as it would give them too greater control over the water flow. The tribunal noted a number of acceptable alternatives that India could make use of for this purpose. ${ }^{174}$

The nature of the tribunal's decision demonstrates the technical knowledge that members of the panel had about the operation of watercourses. When combined with the forthcoming decision, the tribunal has provided the parties with high level technical guidance as to how this dispute should be managed. This is something at that was not seen in the ICJ's decisions that have been

\footnotetext{
${ }^{165}$ Indus Waters, above n 78, at [11]. See Also [12] - [14].

166 At [17].

${ }^{167}$ At [119].

${ }^{168}$ One visit took place before the hearings began, in June 2011, and the other was February 2012. At [7], [81].

${ }^{169}$ Collier and Lowe, above n 47, at 34.

${ }^{170}$ See: Indus Waters, above n 78, at ID.

171 At [437], [442].

${ }^{172}$ At [446].

${ }^{173}$ At [456].

${ }^{174}$ At [517], [518].
} 
discussed previously, which indicates that the nature of the decision given by the body may be impacted by the composition of the decision maker itself.

Despite the more practical nature of the decision, it has yet to be seen whether tribunal's decision will be adhered to by India. It will be also interesting to see if the decision has an impact on the way that India and Pakistan interact in relation to the management of the Indus River in the future.

\section{Not the UN Convention Approach}

The foregoing discussion has demonstrated the mixed approach that states have taken to resolving disputes in the international watercourse context. States have adopted an approach similar to that set out in the UN Convention, although they have not followed the process through to its conclusion.

As was stated in part IV, article 33 of the UN Convention requires states to begin the process of dispute resolution by engaging in negotiations, then using processes such as good officers, mediation, conciliation, the ICJ or arbitration if they are unable to reach a negotiated resolution. If these processes are unable to resolve the matter within six months, the parties can then submit the matter to impartial fact finding. It is this last process of dispute resolution which states have failed to engage with in this context despite its prevalence in other areas of international relations, most notably human rights. ${ }^{175}$

\section{A. Why has fact finding not been used in this context?}

The placement of fact finding at the end of the UN Convention process is likely to have affected its use in this context. Fact finding was put at the end of the UN Convention process to give states an option in the event that the ICJ or an arbitral tribunal did not provide them with a workable solution. This kind of situation was seen in the ICJ's decisions in both the Gabčkovo-

\footnotetext{
${ }^{175}$ Many of the fact finding investigations conducted in the context of human rights make findings which relate directly to international criminal liability and are often used as a the basis for criminal prosecutions. For more information see: Lara Talsma "U.N. Human Rights Fact-Finding: Establishing Individual Criminal Responsibility" (2012) 24(2) Florida Journal of International Law 383; B.G. Ramcharan (ed) International Law and Fact-Finding in the Field of Human Rights (Martinus Nijhoff Publishers, The Hague, 1982); Richard B. Lilich Fact Finding Before International Tribunals (Transnational Publishers, New York, 1992).
} 
Nagymaros and Pulp Mills on the River Uruguay cases. Despite the fact that parties could have used a method of dispute resolution like fact finding in this context they have chosen not to. ${ }^{176}$

States may not have engaged with fact finding at the end of the process because they thought that there was little value in fact finding at that stage in the dispute resolution process. Fact finding is a process by which a commission, traditionally composed of impartial observers, investigates a particular incident in order to "produce a narrative of what actually happened" which may be useful in resolving the dispute. ${ }^{177}$ In doing this the fact finding body does not attribute blame to any party, nor does it come to conclusions on legal liability. ${ }^{178}$ One of the benefits of engaging in this type of investigation is to narrow the range of disagreements between the parties to the dispute. ${ }^{179}$ As the process has developed over time, the tasks undertaken by fact finding commissions have broadened and they have increasingly started to give information on the legal principles in a particular area as well as make recommendations for future action as part of their reports.

If the role of a fact finding commission is merely to clarify the facts of a particular situation it seems somewhat obsolete after both parties have put their views on the situation to an independent body so that they can make a determination on the factual and legal position. This is even more so when combined with the ability of both the ICJ and arbitral tribunals to make their own inquiries in conjunction with the evidence put to them by the parties to the dispute. ${ }^{180}$

Further, fact finding may not have been engaged with under the UN Convention process because it can be overridden by specific agreements that co-riparian states have put in place for the

\footnotetext{
${ }^{176}$ It must be remembered that the Gabčikovo-Nagymaros case was decided before the UN Convention was drafted, so the rules were not available to provide assistance in that situation. Despite this fact finding was a dispute resolution process that existed and was available to the parties at the time, and they chose not to make use of it.

${ }^{177}$ Palmer, above $\mathrm{n} 3$, at 66.

${ }^{178}$ Convention for the Pacific Settlement of International Disputes, above n 56, art 35; Palmer, above n 3, at 66; Collier and Lowe, above n 47, at 24.

${ }^{179}$ Arthur Lenk "Fact Finding as a Peace Negotiation Tool - The Mitchell Report and the Israeli-Palestinian Peace Process" (2002) 24(3) Loyola of Los Angles International Law Review 289 at 291.

${ }^{180}$ Statute of the International Court of Justice, art 50. Although the court only rarely makes use of these powers, instead preferring to use the expert evidence provided by the parties. See: Zimmermann, Tomuschat, Oellers-Frahm and Tams, above $\mathrm{n} 82$, at $1287-1299$. The ability of arbitrators to appoint experts depends on the rules which apply to the arbitration, although often the expert evidence presented by the parties is enough when combined with the knowledge of the arbitrators presiding. Merrils International Dispute Settlement, above n 3, at 99. The rule in commercial arbitration applies in the same manner, see: Nigel Blackaby and Constantine Partasides with Alan Redfern and Martin Hunter Redfern and Hunter on International Arbitration: Student Version $\left(5^{\text {th }}\right.$ ed, Oxford University Press, Oxford, UK, 2009) at [5.22] - [5.23], [6.152] - 6.159].
} 
management of the watercourses that they share. ${ }^{181}$ Some agreements of this nature were discussed in section IV, and these examples demonstrate that these agreements often place institutions which produce binding disputes at the end of the dispute resolution process.

These reasons go somewhat to explaining why a process like fact finding has not been used when parties to a dispute have been unable to reach a result through other means, as is suggested in the UN Convention. However, the UN Convention is a relatively recent development and fact finding has a much longer history. The concept was contained in the Hague Conventions on the Pacific Settlement of Disputes of 1899 and 1907, although it was known in those agreements as a Commission of Inquiry. ${ }^{182}$ Although this historical formulation saw fact finding as unsuitable where issues of vital interests and honour were at stake, which could include rights to watercourses, this perception has changed over time. ${ }^{183}$ Now fact finding is viewed as suitable for a wide range of disputes. ${ }^{184}$ In light of fact findings long history it seems strange that it has only been used to a limited extent in this area, mainly in the work undertaken by joint commissions.

One of the key reasons why fact finding has not been engaged with more in this context is that for the process to be effective in helping to resolve a dispute it requires states to be prepared to concede that their view of the situation is incorrect to some extent. ${ }^{185}$ Some states will be unwilling to concede that their view of the situation may be mistaken, and it is often in these situations that the matter is taken to an adjudicative process for determination. Those states which feel able to concede that their view may be incorrect are likely to be willing to cooperate with the other state involved in order to reach a negotiated solution, particularly if there is no joint commission involved in the management of the watercourse concerned. This means that there is likely to be little scope where fact finding could be invoked in the dispute resolution process. Its main role would be in situations where parties needed clarification on the facts to allow those negotiations to move forward.

Fact finding in this context may also prove problematic for states as it requires a level of cooperation between the parties that may not be possible due to tensions, both related to the dispute and more broadly. ${ }^{186}$ The process of fact finding requires the states concerned to give the

\footnotetext{
${ }^{181}$ Watercourse Convention, above $\mathrm{n} 4$, art 3.

${ }^{182}$ International Convention for the Pacific Settlement of International Disputes 187 CTS 410 (Signed 29 July 1899), art 9 - 14; Convention for the Pacific Settlement of International Disputes above 56, art 9 - 36.

${ }^{183}$ Merrils International Dispute Settlement, above n 3, at 46.

${ }^{184}$ At 59.

${ }^{185}$ Lenk, above n 179, at 293; Merrils International Dispute Settlement, above n 3, at 63.

${ }^{186}$ See: Lenk, above n 179; Palmer, above n 3, at 67.
} 
relevant body access to the areas in dispute so that they can gather evidence in order to determine what has happened, or the potential factual implications of a given action. This process can involve requiring access to official documents, relevant sites and an ability to interview effected persons. Some states may find this too much of an intrusion into their sovereignty and prefer to supply their own version of the facts to the other state concerned. This makes the objective nature of fact finding difficult and therefore the process may not be engaged with.

\section{A Possible Approach for States}

Despite the fact that many states have not yet engaged with fact finding in the context of international watercourse disputes the concept is one that could be very beneficial in this area. The following section provides an alternative framework for dispute resolution. It has been structured in a way that seeks to harness the benefits of fact finding at an early stage, and has also taken into account states preferences to use third party adjudication as a final stage in dispute settlement. ${ }^{187}$ It is hoped that this new structure is able to resolve disputes related to watercourses in an expedient manner.

The proposed dispute resolution framework could be put in place by states establishing a treaty to govern the management of a shared watercourse. Over time these types of agreements are going to become more important to ensure that watercourses are maintained in a way that allows the resource to be preserved for future generations. ${ }^{188}$

This structure can also be adopted on an ad hoc basis by states that do not have their own measures in place relating to dispute resolution, or where those structures are limited. As the UN Convention is not yet in force states are not as risk of breaching international law by using this alternative framework. Although those states who have signed the convention are under an "obligation not to defeat the object and purpose of the treaty prior to its entry into force" the proposed structure is not a sufficiently large departure from the UN Convention to be seen as a breach of that obligation. ${ }^{189}$ The new approach contains the same essential elements as the UN Convention approach and maintains the overall goal of settling disputes by peaceful means. ${ }^{190}$

\footnotetext{
187 Spain, above n 104, at 20.

${ }^{188}$ Lake Lanoux, above n 142, at 124.

${ }^{189}$ Vienna Convention on the Law of Treaties 1155 UNTS 331 (Opened for Signature 23 May 1969, Entered into Force 27 January 1980), art 18. “A state's act will defeat the treaty's object and purpose if it renders meaningless subsequent performance of the treaty". Mark E. Villiger Commentary on the 1969 Vienna Convention on the Law of Treaties (Martinus Nijhoff Publishers, The Netherlands, 2009) at 249. For more see: 242 - 253.

${ }^{190}$ Watercourse Convention, above n 4, art 33(1).
} 
Further the UN Convention allows states to enter into alternative arrangements which adjust the provisions of the UN Convention. ${ }^{191}$

\section{A. Joint Commissions and Fact Finding}

Under the proposed framework the first step for a state to take after a dispute or disagreement over a shared watercourse has become apparent is to engage a joint commission if one is operating. These bodies are often created when states enter into an agreement for the management of a shared watercourse. Those who work within the bodies normally have high levels of knowledge on the daily management of the watercourse.

The UN Convention's preparatory materials demonstrate that the ILC thought that joint institutions were important in this area. In his 1990 report Special Rapporteur Stephen McCaffery suggested that although the formation of a joint commission was not required at international law, it is a form of cooperation "that is almost indispensable if anything approaching optimum utilisation and protection of the system of waters is to be attained". ${ }^{192}$ This institution aids in building the relationships between the riparian states. Since this time, the utility of joint commissions has been shown through their increasing use, leading some to suggest that the creation of a joint commission as part of an agreement in relation to an international watercourse is required as a matter of customary international law. ${ }^{193}$

In responding to a dispute, or disagreement, the joint commission should engage in a process similar to fact finding in order to objectively determine the nature of the dispute, the factual situation and the possible ways it could be resolved. As joint commissions are often staffed by technical experts they are particularly well suited to taking on a role like this. This approach has been used successfully by the IJC, as discussed in section V. ${ }^{194}$ If the joint commission does not contain technical experts a separate body with the required expertise should be appointed to assist the joint commission in this task.

If a joint commission is not in place, or the commissioners do not have the required expertise, it is advisable for the states to establish a fact finding commission to undertake a similar

\footnotetext{
191 Art 3(3).

${ }^{192}$ McCaffery, above $n$ 72, at [7].

${ }^{193}$ Although the use of these institutions may be required, there is still some uncertainty around the scope of their role. Laurence Boisson de Chazournes "The Role of Diplomatic Means of Solving Water Disputes: A Special Emphasis on Institutional Mechanisms" in The International Bureau of the Permanent Court of Arbitration (ed) Resolution of International Water Disputes (Kluwer Law International, The Hague, 2003) 91 at 105.

${ }^{194}$ McCaffery, above n 72, at 52.
} 
investigation. ${ }^{195}$ The UN Convention provides guidance on how fact finding commissions in this context should operate. This model differs from traditional commissions of inquiry and can be seen to more closely reflect a joint commission structure. The UN Convention recommends that each state that is party to the dispute has a representative on the fact finding committee, which has an independent chairperson. This is in contrast to a traditional fact finding commission composed solely of independent commissioners. This new structure is important as it allows states to have a sense of ownership over the process and may help in encouraging them to fully participate in the process and provide the commission with relevant information. ${ }^{196}$

The ability of the fact finding commission to gather information can be hampered if the relevant states are unwilling to cooperate in the process and will not let the panel have access to official information. However a lack of cooperation from the state does not stop the commission interviewing people involved or impacted by a project, although they do not have the power to compel individuals to give evidence. ${ }^{197}$ The inclusion of state representatives on the fact finding commission also helps to alleviate any perception that the commission may be bias in its interpretation of the facts or the recommendations that it puts to states.

Although the presence of state representatives is important, the presence of an independent expert is also of value. This person may be able to explore the problem in more detail through gaining information that a state may not have been willing to share if a direct request was made by the other state concerned.

Through its inquiries the fact finding commission would investigate a given situation and objectively determine the facts. ${ }^{198}$ For example, this could involve examining a proposed hydroelectricity station in order to determine its potential impact on a downstream riparian state. This could include getting technical evidence from a number of sources as to how the plant would impact the flow of the watercourse at all times of the year, how it would impact local communities and examine any environmental impacts the project may have. After the investigation was complete the findings of the fact finding commission would be presented to the parties.

\footnotetext{
195 The fact finding commission in this context would be established by the relevant states, rather than be implemented by the United Nations which is the case with many of the fact finding commissions in the UN Context. For examples see Talsma, above n 175.

${ }^{196}$ Palmer, above n 3, at 64.

${ }^{197}$ At 64.

${ }^{198}$ Convention for the Pacific Settlement of International Disputes, above n 56, art 35.
} 
In order for the fact finding process to be of value in the dispute resolution context it is likely to be helpful to states if the commission departs from the traditional position that fact finders merely provide an outline of the facts, and move towards providing the parties with suggestions as to how to resolve the dispute, which is suggested in the UN Convention. However, suggesting possible resolutions to the dispute does still not give the commission scope to directly attribute blame or make findings of legal liability. Distinguishing between providing factual information and assessing legal liability can be hard for fact finding commissioners. It is something that they must attempt to do as best they can. This may involve the commission providing the parties with separate outlines of the relevant facts and law, but not applying one to the other. This allows the parties to be fully informed about the situation.

In providing the disputing states with recommendations the commission is also not providing the states with a resolution to the dispute. The states must consider the options put forward in good faith and make a decision how to proceed. This approach to the operation of fact finding commissions makes them of little difference to a joint commission. ${ }^{199}$

\section{Why should fact finding be used as a first step?}

This placement of the fact finding process is very different from the UN Convention, however the process has a lot of value if used promptly after a dispute arises. Placing the use of fact finding as early in the process as possible is one way limiting the possibility that the states will reach an impasse in negotiations and refuse to cooperate further. This was one of the hindrances to states engaging with the process that was discussed in the previous section.

It is important to objectively determine the facts of a particular situation at an early stage as these are often crucial for the resolution of the dispute. This is particularly true in the watercourse context. The principles of international law which apply to the sharing of international watercourses, set out previously in section III, demonstrate the primacy of facts in this context. ${ }^{200}$ For example theses principles require a state not to harm a co-riparian through its use of the watercourse. In order to determine if a state has breached its obligations under this principle, the implications of the activity must be determined in order to be able to go on to assess whether they have or will cause harm to the other state.

\footnotetext{
199 Tanzi and Arcari, above n 5, at 284.

${ }^{200}$ McCaffery, above n 7, at 26.
} 
Moreover, often disputes arise because a state is unaware of all the facts in a given situation or they may "have a misconception about the state of things". ${ }^{201}$ Providing states with clear information about the dispute at an early stage can help to stop the matter intensifying. An impartial investigation of the facts can also help the parties to resolve the matter, as the process can remove some points of conflict.

A practical reason for engaging in fact finding early is that the availability of information is generally at its highest at the time the problem emerges and decreases over time. ${ }^{202}$ This is particularly relevant if the question relates to the harm being caused by a development. People in the effected regions are likely to have much better recall the closer to the time the impact is felt.

The scope of information that can be gathered by a fact finding commission is very broad. They are able to get information from anyone involved in the process. This is important as it helps to include groups that are unable to participate in more mainstream dispute resolution processes, despite their interest in the matter, including non-governmental organisations. These organisations are particularly important in this sphere as they often hold a lot of information on the environmental impact of particular projects which can make the fact finders report more comprehensive.

It is envisaged that through providing states with an objective explanation of the facts, and some suggestions as to how to resolve the matter it will provide them a good basis to begin negotiations from. As Stephen McCaffery commented: ${ }^{203}$

... a non-binding expert report, possibly accompanied with a recommended course of action, will frequently result in resolution of an actual or potential dispute without the need to have recourse to a procedure that results in a binding settlement.

An approach of this kind, by using a joint commission or similar institution as a first stage in dispute resolution, is reflective of state practice. It seems that there has been a move by states towards more amicable and cooperative forms of dispute settlement which has been evidenced

\footnotetext{
${ }^{201}$ Kamil Idris and Mpazi Sinjela "The Law of the Non-Navigational Uses of International Watercourses: The International Law Commissions Draft Articles - An Overview" (1995) 3 African Yearbook of International Law 183 at 200 .

${ }^{202}$ Merrils International Dispute Settlement, above n 3, at 51.

${ }^{203}$ Stephen C McCaffery Second Report on the law of the non-navigational uses of international watercourses A/CB.4/399 (1986) at [41].
} 
through an "almost universal endorsement by watercourse states of institutional mechanisms as a first line of dispute avoidance". ${ }^{204}$

Although maintaining a joint commission, or establishing a fact finding commission may involve extra costs for states these processes have a high chance of resolving the dispute at first instance. ${ }^{205}$ This is likely to save states a lot of money in the long term as they do not have to finance an often long, drawn out dispute through the courts or arbitration.

\section{B. Negotiation}

If the process of fact finding is unable to move the parties towards a resolution of the matter, the next stage in the process should be one of direct negotiation between the state parties. This may be at a departmental, ministerial or head of state level depending on the severity and nature of the issue. These negotiations will also be able to take the benefit of the information established in the fact finding process. ${ }^{206}$ The suggestions for resolution of the dispute put forward during the fact finding process can provide states with a starting point for these negotiations.

Negotiations may have more success in coming to a resolution due to the fact that the solutions which may be suggested in the context of negotiations may be more extensive than those put forward during earlier deliberations by a joint commission. Governments are able to bring different factors and policy positions onto the table in a way that a fact finding commission or joint commission are not. The resolution to a dispute may involve bargaining rights to one resource against another which only a government has the ability to do. However, these intergovernment deals are rarely made public and so the frequency of their occurrence and their exact nature is unknown.

If states find it difficult to engage in negotiations directly, perhaps due to strong political tensions, they may seek the aid of a third party during this process. This assistance could be in the form of good offices or mediation. This intervention is aimed at assisting the states to reach a resolution themselves, which allows the result and process to remain under the states' control. This assistance can come from a number of sources including other states, the Secretary General of the UN, UN departments and other non-governmental organisations. A party may volunteer their services if they see the states struggling to resolve the dispute or the states can request assistance themselves.

\footnotetext{
${ }^{204}$ Wouters, above n 1, at 116. See Also:.Salman, above n 57, at 198-9; Palmer, above n 3, at 72.

${ }^{205}$ States normally divide the costs of these institutions between themselves. Mostert, above n 65, at 29.

${ }^{206}$ Spain, above n 104, at 11.
} 
The limited number of cases in this area that have progressed further in the dispute resolution process than negotiation indicates that generally the combination of a joint commission or fact finding process and negotiations between the states concerned will be able to produce an acceptable resolution to the dispute.

\section{Arbitration and the ICJ}

Although it is envisaged that most disputes will be resolved through the use of fact finding, joint commissions and negotiations, these methods are not perfect and it is likely that there will remain a small class of disputes which require a further dispute resolution process. This model suggests that this final stage should provide for recourse to a binding third party decision maker in the form of arbitration or the ICJ. If states are aware that these options are the only alternative to reaching a negotiated solution, it is likely to encourage the states to settle the dispute at an earlier stage due to the time and cost involved in adjudication and arbitration. ${ }^{207}$

Hearings, both at the ICJ and arbitral tribunals, can be costly and time consuming exercises. Although arbitration is generally thought of as being a more expedient method, costs are still high when compared with other methods of dispute resolution that states have available. ${ }^{208}$ Because of this states are better to make use of other forms of dispute resolution as a first stage before beginning a court or arbitral process.

Even if the earlier processes of dispute resolution did not help to resolve the dispute they may help in reducing the time and costs later. This is because states already have access to large amounts of factual information on the dispute, and often the matters at issue between the states have been narrowed as a result of earlier attempts to reach a resolution. This can help to reduce the time, and in turn the costs, of an adjudicative or arbitral process.

As was noted in section $\mathrm{V}$, before a matter can be put before either the ICJ or an arbitral body the consent of the states bringing the action needs to be obtained. ${ }^{209}$ This can either be obtained on an ad hoc basis, or states can give standing consent.

\footnotetext{
${ }^{207}$ Palmer, above n 3, at 74.

${ }^{208}$ Collier and Lowe, above n 47, at 34.

${ }^{209}$ Statute of the International Court of Justice, art 36; Zimmermann, Tomuschat, Oellers-Frahm and Tams, above $\mathrm{n}$ 82, at 660 - 691; Merrils International Dispute Settlement, above n 3, at 91.
} 
Providing for third party adjudication as a method of last resort is very different from the compromise option adopted in the UN Convention. Despite this state practice indicates that states involved in these kinds of issue prefer an approach of this kind.

One reason for states preferences is that the processes produces a binding decision which it is hoped will bring the dispute to an end in an efficient manner. This can be achieved through arbitration and adjudication because decisions of both arbitral tribunals and the ICJ are final and binding. ${ }^{210}$ Past experience has shown that states generally comply with the decisions handed down by both institutions in order to maintain good relations within the international community. ${ }^{211}$ The ICJ has the additional benefit of having a mechanism to enforce judgments handed down if required, however the Security Council will only intervene to enforce judgments in the most serious cases and has not acted in this role to date. ${ }^{212}$

These processes have also been placed at the end of the dispute resolution model because of the detrimental impact that they may have on the relations between the states engaged in the dispute. The adversarial nature of theses process mean that they are forums where states make their positions clear, and where states are, in theory, not willing to compromise. The processes also bring issues into the public forum which can increase the tensions surrounding the matters being heard. This is why states often only resort to these processes when negotiations have met a stalemate or tensions are so high that negotiations are unworkable. At this point there are few other options left which do not require the parties to cooperate.

It is simple to say that states should take any unresolved claims to the ICJ or an arbitral tribunal for final resolution, but if both of these options are placed in a dispute resolution structure it is important for states to know how to determine which option to use in a given situation.

\section{Potential Distinction between Adjudication and Arbitration}

It is likely to be most beneficial for states to allow for recourse to both institutions when forming their watercourse agreements. However there are some differences between the structure and practices of each institution which mean that they are likely to be better suited to different kinds of disputes.

\footnotetext{
${ }^{210}$ Merrils International Dispute Settlement, above n 3, at 110-111, 171. In the arbitration context the ability to appeal is contained in the arbitration agreement, but generally there is little scope for this to occur in the inter-state context.

${ }^{211}$ See: Colter Paulson "Compliance with Final Judgments of the International Court of Justice Since 1987" (2004) 98(3) American Journal of International Law 434; Merrils International Dispute Settlement, above n 3, at 124.

${ }^{212}$ Charter of the United Nations, art 93(2); Wolf, above n 81, 337.
} 
A potential way to distinguish between which matters should be submitted to each institution is to look at the outcome that the states seek from the process. That is, whether they are seeking redress for harm done, or whether they wish to come to a practical settlement about a development project. If the matter relates to the search for redress for the breach of international law or a treaty the matter should be heard by the ICJ. The redress sought in these kinds of situations could include declarations for breaching international law, orders to remove structures from the watercourse or compensation of a different kind. ${ }^{213}$ Whereas if the case relates to a development project, particularly if it has yet to be undertaken or completed, which the party wishes to be altered to respect their rights, the matter is likely to be better dealt with if it is addressed by an arbitral tribunal. The tribunal is able to address the parties positions and look to find a practical way forward, respecting both sides interests.

This distinction reflects the institutions structures, particularly the composition of the decision maker. In the ICJ context the bench is composed of experts in the field of international law. ${ }^{214}$ In arbitration the tribunal can be, and often is, composed of individuals with technical knowledge in the relevant field. ${ }^{215}$ This allows them to develop practical solutions in order to modify developments to fall within set guidelines, which those with only a legal knowledge may not have the skill set to do by themselves. ${ }^{216}$ An arbitral tribunal's ability to look outside the confines of international law if requested to do so by the parties also aids in their ability to find a practical solution to the matter at hand. ${ }^{217}$

\footnotetext{
${ }^{213}$ The ICJ has discretion over the nature of the remedies it awards; it may include declaratory judgments and compensation. For more information on remedies see: Ian Brownlie "Remedies in the International Court of Justice" in Vaughn Lowe and Malgosia Fitzmaurice (eds) Fifty Years of the International Court of Justice (Cambridge University Press, Cambridge, UK, 1996) 30.

${ }^{214}$ There are a range of criteria that govern the eligibility of individuals for the bench of the ICJ including independence, impartiality, high moral character, and recognised competence. See: Statute of the International Court of Justice, art 2; Zimmermann, Tomuschat, Oellers-Frahm and Tams, above n 82, at 233- 247.

${ }^{215}$ Collier and Lowe, above $n$ 47, at 33.

${ }^{216}$ Gray and Kingsbury, above n 48, at 111.

${ }^{217}$ The ICJ is able to make determinations ex aequo et bono (on the basis of equity) if requested to do so by the parties under article 38(2) of the Statute of the International Court of Justice, but a state has yet to make this kind of request. This is likely reflective of the fact that states perceive the ICJ's main function as determining legal rights and obligations. See: Zimmermann, Tomuschat, Oellers-Frahm and Tams, above $\mathrm{n}$ 82, at 791 - 797. In comparison it has been said that arbitral tribunals have been prepared to depart from established principles of international law and make decisions based on compromises between the parties. However, even in cases where this has been done it has not overridden the legal nature of the decision. Gray and Kingsbury, above n 48, at 115-116.
} 
The difference in expertise was demonstrated in the different outcomes in the cases heard by the different institutions discussed in previous sections of this paper. This distinction in outcome is most noticeable when comparing the ICJ's decisions in Gabč́kovo-Nagymaros and Pulp Mills on the River Uruguay with the arbitral tribunal's decision in Indus Waters, discussed in section V. In Gabcíkovo-Nagymaros and Pulp Mills on the River Uruguay the ICJ knew the parties had breached their obligations, but chose not to provide them with a definitive way forward to resolve the dispute. One explanation for this approach to the case is that the bench did not have technical knowledge required to determine how the states should seek to manage the watercourse in the future. Sending the parties back to negotiations in light of clarifying their legal rights had mixed results in these cases, with a negotiated agreement being reached in Pulp Mills on the River Uruguay and not in Gabčikovo-Nagymaros. In Indus Waters the tribunal is seeking to provide firm limits in order to protect Pakistan's right to the waters as members of the tribunal have the technical knowledge to apply the scientific material before them, however, it remains unclear how effective this decision will be.

This is only one potential way in which states can choose between arbitration and adjudication. There may be other factors which guide states choices. States decisions can be impacted by the different standards of confidentiality between the two institutions, the ability to choose the decision maker and any time constraints that the states concerned are under. Other factors may include the ability of third states to intervene in the process and the practice of the respective institutions in relation to appointing experts. ${ }^{218}$ Determining which institution to refer a dispute to will always be a matter to be determined by the parties in the particular circumstances.

\section{The International Law Commissions Approach}

The suggested dispute resolution structure put forward in this paper is based on the dispute resolution provisions suggested early in the UN Conventions development. The thoughts of a series of Special Rapporteurs have been combined with state practices to form the structure outlined in the previous section.

The first Special Rapporteur involved in the drafting of the dispute resolution provisions for the ILC was Stephen Schwebel. Through his reports he suggested a four stage process for the

\footnotetext{
${ }^{218}$ It is much easier for interested third party states to intervene in the ICJ process. There are two situations allowing for intervention at the courts discretion, article 62 allows states to intervene if they have an interest of a legal nature which may be impacted by the action, and article 63 allows states that are party to the treaty being discussed to intervene. This is different from arbitration which requires the states' consent before another party can be involved in the process. For more information on these provisions see: Zimmermann, Tomuschat, Oellers-Frahm and Tams, above n 82, at 1529 - 1597; Gray and Kingsbury, above n 48, at $112-113$.
} 
resolution of disputes. The first stage involved a commission of inquiry investigating the dispute. It appears that he foresaw the inquiry to have a traditional role in supplying the parties with an overview of the facts, but not suggestions as to how to resolve the disputes. ${ }^{219}$ The report indicates that states should then proceed to negotiate on the basis of the information put forward by the independent commission. If no solution was able to be reached through negotiations after six months, states could submit the matter to conciliation. ${ }^{220}$ Conciliation involves an independent panel investigating the facts and making suggestions for settlement. ${ }^{221}$ The options for settlement put forward by the conciliation commission were not binding on the parties. Over time the process of fact finding, or inquiry, has moved closer to that of conciliation, and in the framework suggested in this paper the two forms of dispute resolution have effectively been combined into one stage. The final stage of Schwebel's dispute resolution framework applied if the recommendations of the commission proved to be unacceptable to one or more of the parties. In this situation the matter could be referred to arbitration or adjudication after 90 days. ${ }^{222}$

The dispute resolution structure put forward by Schwebel was endorsed by subsequent Special Rapporteurs. Although Jens Evensen and Stephen McCaffery made minor alterations to the time required before the next stage in resolving the dispute could be progressed to they accepted the proposal. They believed that it reflected the need for technical expertise in this area and thought that the options presented were likely to be politically acceptable. ${ }^{223}$

The model suggested in this paper does not place time limits on any stage in the process to allow states to have the greatest opportunity to resolve the dispute in the manner that they choose. If states choose to put a structure of this kind into a treaty there is scope for them to include time limits at each stage, and this may alter the emphasis that is placed on each stage of the process.

The framework for dispute resolution that was put forward in the final draft, and commented on by member states of the UN was substantially different from that put forward in the earlier drafts. The final Special Rapporteur on the project, Robert Rosenstock, altered the structure of the dispute resolution article due to time constraints on the drafting process. His version required states to engage in direct negotiations, with the option of using fact finding if negotiations were unsuccessful. ${ }^{224}$ It then required that if no outcome had been reached within one year states

\footnotetext{
${ }^{219}$ Schwebel, above n 31, at [498].

${ }^{220}$ At [498].

${ }^{221}$ Collier and Lowe, above $\mathrm{n} 47$, at 29.

${ }^{222}$ Schwebel, above n 31, at [498].

${ }^{223}$ Evensen, above n 77, at 204-227; McCaffery, above n 72, at 78.

224 Robert Rosenstock Second Report on the law of the non-navigational uses of international watercourses A/CN.4/462 (1994) at [41].
} 
should submit their dispute to binding arbitration. ${ }^{225}$ This final part was amended by the drafting committee to allow for recourse to the ICJ as well as arbitration. ${ }^{226}$ This was the version submitted as part of the UN Conventions first draft.

However, as was discussed in section IV, states did not agree that this kind of structure should be followed in a framework convention. It was due to the reaction of the states, and the desire to get the principles of the convention accepted that alterations were made to the dispute resolution aspects of the convention. The final structure, as seen in the UN Convention, was adopted without lengthy discussion as to its consequences. ${ }^{227}$ However, the benefits of the process suggested in this paper should be examined by states before they dismiss it based on its final stage requiring the use of the ICJ or arbitration. This is because the vast majority of cases will never reach that stage in the process. Moreover it always remains up to the states concerned to determine how consent to the processes will be given. This means that states cannot be forced to attend the ICJ or arbitration, which appears to be the main fear when it was suggested that these be included as the final stages in the UN Convention.

\section{Conclusion}

As the global population continues to grow our need for resources will increases with it. This growth is likely to increase the risk that states are going to be involved in disputes as to how scare resources should be shared. To stop these disputes from escalating these matters need to be resolved as quickly as possible. The dispute resolution structure provided in the UN Convention does not provide the optimum structure for this as one of the most valuable processes, fact finding, is left to the final stage of the framework.

For this reason the preceding paper has proposed an alternative framework for the resolution of disputes involving the development of international watercourses. It is hoped that this structure will allow disputes to be resolved in an efficient manner by using fact finding at an early stage in the process. It is hoped that the advantages of fact finding explored in this paper will encourage states to use the process, both within this context and in resolving international disputes more broadly.

\footnotetext{
${ }^{225}$ At [41].

${ }^{226}$ Draft articles on the law of the non-navigational uses of international watercourses: Titles and texts of the articles adopted by the Drafting Committee on second reading (A/CN.4/L.492 (1994).

${ }^{227}$ Wouters, above n 32, at 22, footnote 107.
} 


\section{Bibliography}

A. Cases

1. International Court of Justice

Certain Activities Carried Out by Nicaragua in the Border Area (Costa Rica v Nicaragua) (Application Instituting Proceedings) (International Court of Justice, General List Number 150, 18 November 2010).

Certain Activities Carried Out by Nicaragua in the Border Area (Costa Rica v Nicaragua) (Provisional Measures) [2011] ICJ Rep 6.

Construction of a Road in Costa Rica Along the San Juan River (Nicaragua v Costa Rica) (Application Instituting Proceedings) International Court of Justice, General List Number 152, 22 December 2011).

Diversion of Water from the Meuse (Netherlands v Belgium) (1937) PCIJ (series A/b) No 70.

Fisheries Jurisdiction Case (United Kingdom v Iceland) [1974] ICJ Rep 3.

Gabcikovo-Nagymaros Project (Hungary v Slovakia) [1997] ICJ Rep 7.

LaGrand (France v United States of America) [2001] ICJ Rep 466.

Land and Maritime Boundary between Cameroon and Nigeria (Cameroon v Nigeria: Equatorial Guinea Intervening) [1998] ICJ Rep 275.

Mavommatis Palestine Concessions (Greece v Britain) (1924) PCIJ (series A) No 2.

North Sea Continental Self (Germany v Denmark) [1969] ICJ Rep 3.

Pulp Mills on the River Uruguay (Argentina v Uruguay) [2010] ICJ 14.

3. Arbitration Awards

Indus Waters Kishengana (Pakistan v India) (Partial Award) PCA 18 February 2013. 
Kushk River (Great Britain (Afghanistan) v Russia) Anglo-Russian Commission 22 August 1893.

Lake Lanoux (France v Spain) (1957) 24 ILR 101.

Award in Regard to the Validity of the Treaty of Limits between Costa Rica and Nicaragua (Costa Rica v Nicaragua) (1888) 28 RIAA 189.

Tacna-Arica Question (Chile v Peru) (1925) 2 RIAA 921.

\section{B. Treaties}

Agreement Between the Government of the French Republic and the Spanish Government Relating to Lake Lanoux 796 UNTS 235 (Signed July 12 1958).

Charter of the United Nations.

Convention on the Law of the Non-Navigational Uses of International Watercourses (Opened for signature 25 May 1997, not yet in force).

Convention for the Pacific Settlement of International Disputes 205 CTS 233 (Signed 18 October 1907).

Exchange of Letters Constituting an Agreement Between France and Spain Amending the Arrangement of 12 July 1958 Relating to Lake Lanoux 796 UTS 240 (Entered into Force 27 January 1970).

Indus Waters Treaty, India-Pakistan 419 UNTS 126 (Signed 19 September 1960).

International Convention for the Pacific Settlement of International Disputes 187 CTS 410 (Signed 29 July 1899).

Special Agreement for submission to the International Court of Justice of the differences concerning the Gabcikovo-Nagymaros Project 1725 UNTS 226 (Signed 7 April 1993).

Statute of the International Court of Justice .

Statute of the River Uruguay, Uruguay-Argentina 1295 UNTS 340 (Signed 26 February 1975). 
Treaty Between Great Britain and the United States Relating to Boundary Waters and Boundary Questions 208 CTS 213 (Signed 11 January 1909).

Treaty Concerning the Construction and Operation of the Gabčíkovo-Nagymaros System of Locks, Hungary-Czechoslovakia 1109 UNTS 236 (Signed 16 September 1977).

Treaties of Commerce and Navigation, For the Regulation of Drawing s of Water from the Meuse and for the Extinction of the Scheldt Tolls between Belgium and the Netherlands 127 CTS 435 (Signed 12 May 1863).

Vienna Convention on the Law of Treaties 1155 UNTS 331 (Opened for Signature 23 May 1969, Entered into Force 27 January 1980).

\section{United Nations Documents}

Convention on the Law of the Non-Navigational Uses of International Watercourses A/RES/51/299 (1997).

Convention on the Protection and Use of Transboundary Watercourses and International Lakes ECE/MP.WAT/5 (2000).

Draft articles on the law of the non-navigational uses of international watercourse: Titles and texts of the articles adopted by the Drafting Committee on second reading A/CN.4/L.492 (1994).

Management of International Water Resources ST/ESA/5 (1975).

Press Release: General Assembly Adopts Convention on Law of Non-Navigational Uses of International Watercourses GA/9248 (1997).

Progressive development and codification of the rules of international law relating to international watercourses GA Res 2669 A/Res/2669 (1970).

Text of the preamble $\left(1^{\text {st }}, 5^{\text {th }}\right.$ and $8^{\text {th }}$ paragraphs), articles 2(c), 8(1), 12 (title), 17(3), 18, 20 and 30 and annex (Arbitration) adopted ad referendum by the Working Group of the Whole: $6^{\text {th }}$ Committee, Working Group of the Whole for the Elaboration of a Convention on the Law o the Non-Navigational Uses of International Watercourses A/C.6/51/NUW/WG/L.3/Add.1 (1997). 
J Evensen First Report on the law of the non-navigational uses of international watercourses A/CN.4/367 and Corr.1 (1983).

Robert Rosenstock Second Report on the law of the non-navigational uses of international watercourses A/CN.4/462 (1994).

Stephen C McCaffery Second Report on the law of the non-navigational uses of international watercourses A/CB.4/399 (1986).

Stephen C McCaffery Sixth Report on the law of the non-navigational uses of international watercourses A/CN.4/427 (1990).

Stephen M Schwebel Third Report on the law of non-navigational uses of international watercourses A/CN.4/348 and Corr.1 (1982).

D. Books

Freidrich Joseph Berber Rivers in International Law (Stevens and Sons, London, 1959).

Nigel Blackaby and Constantine Partasides with Alan Redfern and Martin Hunter Redfern and Hunter on International Arbitration: Student Version ( $5^{\text {th }}$ ed, Oxford University Press, Oxford, UK, 2009).

Lucius Caflisch Promoting Justice, Human Rights and Conflict Resolution through International Law (Martinus Nijhoff Publishers, Leiden, the Netherlands, 2007).

John Collier and Vaughan Lowe The Settlement of Disputes in International Law (Oxford University Press, Oxford, UK, 1999).

Guy Olivier Faure and Jeffery Z Rubin (eds) Culture and Negotiation: The Resolution of Water Disputes (Sage Publications, 1993).

Alina Kaczorowska Public International Law ( $3^{\text {rd }}$ ed, Routledge-Cavendish, Oxon, UK, 2005).

Richard B. Lilich Fact Finding Before International Tribunals (Transnational Publishers, New York, 1992). 
Stephen C McCaffery The Law of International Watercourses (Oxford University Press, Oxford, UK, 2007).

J. G. Merrils International Dispute Settlement $\left(4^{\text {th }}\right.$ ed, Cambridge University Press, Cambridge, UK, 2005).

Eric Mostert Conflict and Co-operation in the Management of International Freshwater Resources: A Global Review (UNESCO, Paris, 2003).

B.G. Ramcharan (ed) International Law and Fact-Finding in the Field of Human Rights (Martinus Nijhoff Publishers, The Hague, 1982).

M.A. Salman and Laurence Boisson de Chazournes (eds) International Watercourses:

Enhancing Cooperation and Managing Conflict (World Bank Technical Paper No. 414, 1998).

Attila Tanzi and Maurizio Arcari The United Nations Convention on the Law of International Watercourses: a framework for sharing (Kluwer Law International, London, 2001).

Mark E. Villiger Commentary on the 1969 Vienna Convention on the Law of Treaties (Martinus Nijhoff Publishers, The Netherlands, 2009).

Sergei Vinogradov, Patricia Wouters and Partricia Jones Transforming Potential Conflict into Cooperation Potential: The Role of International Water Law (UNESCO, Paris, 2003).

Vaughn Lowe and Malgosia Fitzmaurice (eds) Fifty Years of the International Court of Justice (Cambridge University Press, Cambridge, UK, 1996).

Andreas Zimmermann, Christian Tomuschat, Karin Oellers-Frahm and Christian J. Tams (eds) The Statute of the International Court of Justice: A Commentary $\left(2^{\text {nd }}\right.$ ed, Oxford University Press, Oxford, UK, 2012).

\section{E. Chapters from Books}

Ian Brownlie "Remedies in the International Court of Justice" in Vaughn Lowe and Malgosia Fitzmaurice (eds) Fifty Years of the International Court of Justice (Cambridge University Press, Cambridge, UK, 1996) 30. 
Laurence Boisson de Chazournes "The Role of Diplomatic Means of Solving Water Disputes: A Special Emphasis on Institutional Mechanisms" in The International Bureau of the Permanent Court of Arbitration (ed) Resolution of International Water Disputes (Kluwer Law International, The Hague, 2003) 91.

Lusius Caflisch "Regulation of the Uses of International Watercourses" in in M.A. Salman and Laurence Boisson de Chazournes (eds) International Watercourses: Enhancing Cooperation and Managing Conflict (World Bank Technical Paper No. 414, 1998) 3.

Stephen C. McCaffery "International Watercourses" in RJ Dupuy (ed) A Handbook on International Organizations ( $2^{\text {nd }}$ ed, Martinus Nijhoff Publishers, The Netherlands, 1988) 725.

Stephen McCaffery "The UN Convention on the Law of the Non-Navigational Uses of International Watercourses: Prospects and Pitfalls" in M.A. Salman and Laurence Boisson de Chazournes (eds) International Watercourses: Enhancing Cooperation and Managing Conflict (World Bank Technical Paper No. 414, 1998) 17.

Stephen C McCaffery "Water Disputes Defined: Characteristics and Trends for Resolving Them" In The International Bureau of the Permanent Court of Arbitration (ed) Resolution of International Water Disputes (Kluwer Law International, The Hague, 2003) 49.

John Merrils “The Means of Dispute Settlement” in Malcolm D. Evans (ed) International Law $\left(2^{\text {nd }}\right.$ ed, Oxford University Press, New York, 2006) 533.

G.T. Keith Pitman "The Role of the World Bank in Enhancing Cooperation and Resolving Conflict on International Watercourses: The Case of the Indus Basin” in M.A. Salman and Laurence Boisson de Chazournes (eds) International Watercourses: Enhancing Cooperation and Managing Conflict (World Bank Technical Paper No. 414, 1998) 155.

Salman M.A.Salman "Good Offices and Mediation and International Water Disputes in The International Bureau of the Permanent Court of Arbitration (ed) Resolution of International Water Disputes (Kluwer Law International, The Hague, 2003) 155.

Attila Tanzi and Cesare Pitea "Emerging Trends in the Role of Non-State Actors in International Water Disputes" in The International Bureau of the Permanent Court of Arbitration (ed) Resolution of International Water Disputes (Kluwer Law International, The Hague, 2003) 259. 
Patricia Wouters "Universal and Regional Approaches to Resolving International Water Disputes: What Lessons Learned From State Practice?” in The International Bureau of the Permanent Court of Arbitration (ed) Resolution of International Water Disputes (Kluwer Law International, The Hague, 2003) 111.

\section{F. Journal Articles}

“Editorial Comment” (1912) 6(1) American Journal of International Law 149.

Phillip Alston "Introduction: Commissions of Inquiry as Human Rights Fact-Finding Tools" (2011) 105 American Society of International Law Proceedings 81.

Larry Bakken "International Joint Commission: Water Conflicts and Dispute Resolution” (2008) 31 Hamline Law Review 593.

Richard B. Bilder "International Third Party Dispute Settlement" (1989) 17(3) Denver Journal of International Law and Policy 471.

Francis N. Botchway "The International Adjudication Processes and Trans-Boundary Resource Disputes" [2001] Australian International Law Journal 143.

C. B. Bourne "Mediation, Conciliation and Adjudication in the Settlement of International Drainage Basin Disputes” (1971) 9 Canadian Yearbook of International Law 114.

Susan J Buck, Gregory W. Gleason, and Mitchel S. Jofuku "The Institutional Imperative: Resolving Transboundary Water Conflict in Arid Agricultural Regions of the United States and the Commonwealth of Independent States" (1993) 33(3) Natural Resources Journal 595.

Christine Chinkin and Romana Sadurska “The Anatomy of International Dispute Resolution" (1991) 7(1) Ohio State Journal on Dispute Resolution 39.

Andrew Coleman "The International Court of Justice and Highly Political Matters (2003) 4(1) Melbourne Journal of International Law 29.

John R. Crook and Stephen C. McCaffery "The United Nations Starts Work on A Watercourses Convention" (1997) 91(2) American Journal of International Law 374. 
Edwin B. Firmage "Fact Finding in the Resolution of International Disputes: From the Hague Peace Conference to the United Nations" [1971] Utah Law Review 421.

Thomas M. Franck and Laurence Cherkis "The Problem of Fact-Finding in International Disputes" (1966-1967) 18(5) Western Reserve Law Review 1483.

Rebecca Goldbert "The Global Dimension to the Current Economic Crisis and the Benefits of Alternative Dispute Resolution” (2011) 11(2) Nevada Law Journal 502.

Christine Gray and Benedict Kingsbury "Developments in Dispute Settlement: Inter-State Arbitration Since 1945” (1992) 63(1) The British Yearbook of International Law 98.

Cameron Hutchinson "The Duty to Negotiate International Environmental Disputes in Good Faith” 2006 2(2) McGill International Journal of Sustainable Development 117.

Charles Cheney Hyde "The Place of Commissions of Inquiry and Conciliation Treaties in the Peaceful Settlement of International Disputes" (1929) 23 American Society of International Law Proceedings 144.

Kamil Idris and Mpazi Sinjela "The Law of the Non-Navigational Uses of International Watercourses: The International Law Commissions Draft Articles - An Overview" (1995) 3 African Yearbook of International Law 183.

Ruth Lapidoth "Dispute Settlement Under the 1997 Convention on the Law of the NonNavigational Uses of International Watercourses" (2000) 75 International Law Studies 232.

L H Legault "The Roles of Law and Diplomacy in Dispute Resolution: The IJC as a Possible Model” (2000) 26 Canada-United States Law Journal 47.

Arthur Lenk "Fact Finding as a Peace Negotiation Tool - The Mitchell Report and the IsraeliPalestinian Peace Process" (2002) 24(3) Loyola of Los Angles International Law Review 289.

Robert Mandel “Sources of International River Basin Disputes” (1992) 12 Conflict Quarterly 25.

Sarah Mateljan "Water Wars: Preventing and Resolving Conflicts over Transboundary Groundwater Resources” (2007) 14(2) Murdoch University eLaw Journal 178. 
Stephen C McCaffery and Mpazi Sinjela "The 1997 United Nations Convention on International Watercourses" (1998) 92(1) American Journal of International Law 97.

Geoffrey Palmer "Perspectives on International Dispute Settlement from a Participant" (2012) 43 VUWLR 36.

Colter Paulson "Compliance with Final Judgments of the International Court of Justice Since 1987” (2004) 98(3) American Journal of International Law 434.

Cymie Payne "Mastering the Evidence: Improving Fact Finding by International Courts" (2011) 41(4) Environmental Law 1191.

M.M. Rahaman "Principles of International Water Law" (2009) 1(3) International Journal of Sustainable Society 207.

Mohamed Sameh "Diversion of International Watercourses under International Law" (2002) 10 African Yearbook of International Law 109.

Aaron Schwabach "United Nations Convention on the Law of Non-navigational uses of International Watercourses, Customary International Law, and the Interests of Developing Upper Riparian's" (1998) 33(2) Texas International Law Journal 257.

H.A. Smith "The Water of the Jordan: A Problem with International Water Control” (1949) 25(4) International Affairs 415.

Anna Spain "Beyond Adjudication: Resolving International Resource Disputes in an Era of Climate Change” (2011) 30(2) Stanford Environmental Law Journal 343.

Anna Spain "Integration Matters: Rethinking the Architecture of International Dispute Resolution” (2010) 32 University of Pennsylvania Journal of International Law 1.

Lara Talsma "U.N. Human Rights Fact-Finding: Establishing Individual Criminal Responsibility” (2012) 24(2) Florida Journal of International Law 383.

Phillip R. Trimble "International Institutions and the World's Water" (1996) 90 American Society of International Law Proceedings 499. 
Aaron T. Wolf "International Water Conflict Resolution: Lessons from Comparative Analysis" (1997) 13(3) International Journal of Water Resources Development 333.

P Wouters "The Legal Response to International Water Scarcity and Water Conflicts: The UN

Watercourses Convention and Beyond" (1999) 42 German Yearbook of International Law 292.

Zeray Yihdego “The Gaza Mission: Implications for International Humanitarian Law and UN Fact Finding” (2012) 13(1) Melbourne Journal of International Law 1.

\section{G. Other Resources}

\section{Newspaper Articles}

Barbara Crossette "Severe Water Crisis Ahead for Poorest Nations in Next 2 Decades" The New York Times (New York, 10 August 1995).

D. E. Lilenthal “Another Korea in the Making?” Collier's (United States, 4 August 1951).

"Uruguay/Argentina implement the end of the pulp mill dispute" MercoPress (Online ed, Montedideo, Uruguay, 31 August 2010).

"Argentina and Uruguay settle seven-year pulp mill row" $B B C$ (Online ed, London, 16 November 2010).

\section{Press Releases}

International Court of Justice "Gabčíkovo-Nagymaros Project (Hungary/Slovakia): Hungary to file by 7 December 1998 a written statement of its position on Slovakia's request for an additional Judgment" (press release, 7 October 1998).

\section{Online Resources}

Norman Schultz "Joint Fact-Finding (July 2003) < http://www.beyondintractability.org/biessay/joint-fact-finding $>$.

Daniel Seligman "Resolving Interstate Water Conflicts" (June 2011) Institute of Water Policy Working Paper Series <http://lkyspp.nus.edu.sg/iwp/wpcontent/uploads/sites/3/2013/04/IWP_2011_WP002.pdf $>$. 
"Convention on the Law of the Non-Navigational Uses of International Watercourses" United Nations Treaty Database (1 October 2013)

$<$ http://treaties.un.org/pages/ViewDetails.aspx?src=TREATY\&mtdsg_no=XXVII$12 \&$ chapter $=27 \&$ lang $=\mathrm{en}>$. 